\title{
Folklinguistics and Social Meaning in Australian English
}

Folklinguistics and Social Meaning in Australian English presents an original study of Australian English and, via this, insights into Australian society. Utilising folklinguistic accounts, it uncovers everyday understandings of contemporary Australian English through variations across linguistic systems (sounds, words, discourse and grammar). Focusing on one variation at time, it explores young speakers' language use and their evaluations of the same forms. The analysis of talk about talk uncovers ethnic, regional and social Others in social types and prevailing ideologies around Australian English essential for understanding Australian identity-making processes, as well as providing insights and methods relevant beyond this context. These discussions demonstrate that while the linguistic variations may occur in other varieties of English, they are understood through local conceptualisations and often as uniquely Australian.

This book harnesses the value and richness of discourse in explorations of the sociocultural life of language. The findings show that analysis attending to language ideologies and identities can help discover the micro-macro links needed in understanding social meanings. The volume explores a wide range of language features but also provides a deep contemplation of Australian English.

Cara Penry Williams has a master's degree in applied linguistics and a $\mathrm{PhD}$ in linguistics from the University of Melbourne. After many years of teaching and researching at the University of Melbourne and La Trobe University, she is now a lecturer in English Language at the University of Derby in the UK and an honorary research fellow at La Trobe University. 


\section{Routledge Studies in World Englishes}

Series Editor: Ee Ling Low

National Institute of Education, Nanyang Technological University,

Singapore and President of Singapore Association of Applied Linguistics

This Singapore Association for Applied Linguistics book series will provide a starting point for those who wish to know more about the aspects of the spread of English in the current globalized world. Each volume can cover the following aspects of the study of World Englishes: issues and theoretical paradigms, featurebased studies (i.e., phonetics and phonology, syntax, lexis) and language in use (e.g., education, media, the law and other related disciplines).

\section{EIL Education for the Expanding Circle}

A Japanese Model

Nobuyuki Hino

Professional Development of English Language Teachers in Asia

Lessons from Japan and Vietnam

Edited by Kayoko Hashimoto and Van-Trao Nguyen

\section{The Politics of English in Hong Kong}

Attitudes, Identity and Use

Jette G. Hansen Edwards

\section{Topicalization in Asian Englishes}

Forms, Functions and Frequencies of a Fronting Construction

Sven Leuckert

\section{Investigating World Englishes}

Research Methodology and Practical Applications

Edited by Peter I. De Costa, Dustin Crowther and Jeffrey Maloney

\section{Folklinguistics and Social Meaning in Australian English}

Cara Penry Williams

For a full list of titles in this series, visit www.routledge.com/Routledge-Studiesin-World-Englishes/book-series/RSWE 


\title{
Folklinguistics and Social Meaning in Australian English
}

\section{Cara Penry Williams}


First published 2020

by Routledge

2 Park Square, Milton Park, Abingdon, Oxon OX14 4RN

and by Routledge

52 Vanderbilt Avenue, New York, NY 10017

Routledge is an imprint of the Taylor \& Francis Group, an informa business

(C) 2020 Cara Penry Williams

The right of Cara Penry Williams to be identified as author of this work has been asserted by her in accordance with sections 77 and 78 of the Copyright, Designs and Patents Act 1988.

All rights reserved. No part of this book may be reprinted or reproduced or utilised in any form or by any electronic, mechanical, or other means, now known or hereafter invented, including photocopying and recording, or in any information storage or retrieval system, without permission in writing from the publishers.

Trademark notice: Product or corporate names may be trademarks or registered trademarks, and are used only for identification and explanation without intent to infringe.

British Library Cataloguing-in-Publication Data

A catalogue record for this book is available from the British Library

Library of Congress Cataloging-in-Publication Data

A catalog record for this book has been requested.

ISBN: 978-0-367-02933-3 (hbk)

ISBN: 978-0-429-00111-6 (ebk)

Typeset in Times New Roman

by Apex CoVantage, LLC 


\section{Contents}

Figures vii

Extracts viii

Tables $\quad \mathrm{x}$

Acknowledgements $\quad$ xi

List of abbreviations xii

List of transcription symbols xiii

1 Introduction 1

1.1 A background for Australian English 1

1.2 Understanding Australian English via social meanings of variation 3

1.3 Overview of the book 4

2 Conceptualising social meaning

2.1 The processes of social meaning 7

2.2 Language ideologies 8

2.3 Indexicality 12

2.4 Identity 15

2.5 The linguistic form 18

2.6 In conclusion 21

3 Studying social meaning via folklinguistics

3.1 The relationship between social meaning and folklinguistics 27

3.2 The what, why and how of folklinguistic comment 27

3.3 Eliciting folklinguistic commentary 36

3.4 Analysing folklinguistic accounts for social meanings 39

3.5 Context and further details of the study 42

3.6 In conclusion 45 
vi Contents

4 Phonetic and phonological variation

4.1 Overview of variation 51

4.2 START $\sim$ NURSE in derby 55

4.3 TRAP PALM in BATH words 60

4.4 Variation relating to unstressed vowels 73

4.5 TRAP DRESS prelaterally 77

4.6 In conclusion 83

5 Lexical variation

5.1 Overview of variation 89

5.2 Regional lexical variation 92

5.3 Heteronyms 100

5.4 Trademarks 107

5.5 Address terms 110

5.6 In conclusion 115

6 Discourse and grammatical variation

6.1 Overview of variation 120

6.2 Clippings and embellished clippings 121

6.3 (ING) 129

6.4 Pronouns 136

6.5 Final but 144

6.6 In conclusion 152

7 Social types and language ideologies

7.1 Locally salient Others 158

7.2 Language ideologies in Australian English 174

7.3 Conclusion 185

Index 


\section{Figures}

2.1 A conceptualisation of social meaning 8

4.1 Indexical field of $/ \mathfrak{x} / \sim / \mathfrak{e}: /$ according to the literature 64

4.2 Indexical field of $/ \mathfrak{/} / \sim / \mathfrak{e}: /$ in dance according to interviewees 65

4.3 Kelly's /æ/ and /e/ prelaterally in Extract 4.5 82

6.1 (ING) by speaker and grammatical category 131

6.2 Indexical field of final particle but in Australian English 146 


\section{Extracts}

4.1 Helen's discussion of castle 67

4.2 Kelly's discussion of castle and Newcastle 69

4.3 Jacqui's discussion of PALM in dance with a voicing 71

4.4 Jacqui's discussion of reactions to her use of PALM with voicings $\quad 72$

4.5 Kelly's discussion of prelateral /æ/ and /e/ 79

5.1 Discussion of togs, bathers and costume with Melody 93

5.2 Daniel's voicing of lacker band 98

$\begin{array}{ll}5.3 \text { Daniel's voicing of elevator } & 102\end{array}$

$\begin{array}{lll}5.4 & \text { Peter's use of cookie and biscuit } & 104\end{array}$

$\begin{array}{ll}5.5 & \text { Ojal's description using trademarks } \\ 5.6 & 108\end{array}$

$\begin{array}{ll}\text { 5.6 Sarah's discussion of Speedos } & 110\end{array}$

5.7 Daniel's voicing with mate 113

5.8 Ian's voicing with mate 113

5.9 Jacqui's voicing with mate in disagreement - mitigating force $\quad 114$

5.10 Jacqui's voicing with mate in disagreement - distancing 114

6.1 Ian's discussion of word shortening 125

$\begin{array}{ll}6.2 \text { Helen's discussion of shortening } & 125\end{array}$

6.3 Discussion of an $-o$ form with Melody 127

6.4 Kelly's discussion of $/ \mathrm{n} /$ in (ING), negative concord

$\begin{array}{lll}6.5 & \text { Singular they } & 138\end{array}$

6.6 Themselves with a singular antecedent 138

6.7 Themself with a singular antecedent 138

$\begin{array}{lll}6.8 & \text { Untriggered myself } & 139\end{array}$

6.9 I myself in subject noun phrase $\quad 139$

$6.10 I$ I . . myself adverbial intensifier use $\quad 139$

6.11 Another example of $I$. . myself adverbial intensifier use $\quad 139$

6.12 Correcting me to myself $\quad 140$

6.13 Me and $X$ in subject position $\quad 140$

6.14 Sarah's discussion of possessive " $m e$ " 141

6.15 Kelly's voicing of possessive " $m e$ " 143

6.16 Helen's discussion of final particle but 148

$\begin{array}{ll}6.17 \text { Peter's discussion of final particle but } & 148\end{array}$ 
6.18 Discussion of final particle but with Ben with a voicing 150

$\begin{array}{lll}7.1 & \text { Daniel's discussion of ockers } & 160\end{array}$

7.2 Peter's discussion of the ocker accent with a voicing 161

7.3 Neil's discussion of ockers and wogs with a voicing 164

7.4 Jacqui's discussion of the speech of Sydneysiders as woggy 165

7.5 Gavin's discussion of bogany style with voicings 168

7.6 Ian's voicing of a bogan 169

7.7 Kelly's discussion of the speech of Queenslanders 171

$\begin{array}{lll}7.8 & \text { Ojal's description of her speech } & 172\end{array}$

7.9 Regina's discussion of her reaction to negative evaluations

7.10 Evan's response to negative evaluations of Australian English 177

7.11 Daniel's discussion of the Australian accent 178

7.12 Discussion of the Australian accent with Helen 179

7.13 Fiona's discussion of typically Australian 180

7.14 Melody's discussion of typically Australian and clichés 181

7.15 Discussion of changing English with Ben 183

7.16 Melody's discussion of Americanisms and older norms 184 


\section{Tables}

3.1 Summary of interviewees' age and sex 44

4.1 Transcription systems for Australian English vowels 52

4.2 Summary of questionnaire comments on START in derby 56

4.3 Summary of questionnaire comments on NURSE in derby 57

4.4 Summary of questionnaire comments on TRAP in dance 61

4.5 Summary of questionnaire comments on TRAP in castle 62

4.6 Summary of questionnaire comments on PALM in castle 63

4.7 Summary of questionnaire comments on GOAT in ceremony 74

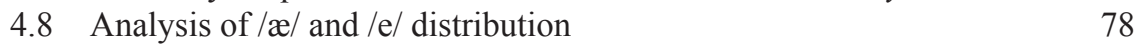

5.1 The properties of cookies and biscuits in contrast 105

6.1 Original forms and alternative clipped and/or embellished forms used 122

6.2 Use of clipped or embellished clipping forms by participant 123

$\begin{array}{ll}6.3 \text { (ING) in -thing words } & 130\end{array}$

6.4 Summary of questionnaire comments on final but $\quad 145$ 


\section{Acknowledgements}

Over the duration of this project and the writing of this book, I have received support from so many people. I hope that I have shown them each my appreciation for their kindness and time.

I would like to more formally acknowledge Jean Mulder, my PhD supervisor, for her encouragement in that role and ongoing engagement in the years since. My thanks also my colleagues at La Trobe University and now at the University of Derby for their support and the staff at the University of Melbourne, School of Languages and Linguistics, before this.

I am also very grateful to all of those who assisted directly in the preparation and production of this book, including the series editor Ee Ling Low, Routledge editor Katie Peace, senior editorial assistant Samantha Phua, project manager Chris Mathews and all the others who were anonymous or who I did not communicate with directly. Thank you all for your efforts and contributions. 


\section{Abbreviations}

$\begin{array}{ll}\text { ABC } & \text { Australian Broadcasting Commission }>\text { Corporation } \\ \text { ABS } & \text { Australian Bureau of Statistics } \\ \text { AmE } & \text { The English of the United States of America } \\ \text { AusE } & \text { Australian English } \\ \text { BrE } & \text { British English } \\ \text { CanE } & \text { Canadian English } \\ \text { EngE } & \text { English English } \\ \text { ICE-AUS } & \text { The International Corpus of English-Australian component } \\ \text { IrE } & \text { Irish English } \\ \text { IU } & \text { Intonation unit } \\ \text { MD } & \text { Macquarie Dictionary, online edition (2003-2019) } \\ \text { NZE } & \text { New Zealand English } \\ \text { RP } & \text { Received Pronunciation } \\ \text { SAfE } & \text { South African English } \\ \text { ScotE } & \text { Scottish English and/or Modern Scots } \\ \text { SES } & \text { Socio-economic status } \\ \text { SRT } & \text { Subjective reaction test }\end{array}$




\section{Transcription symbols}

Reference list of discourse transcription symbols: "DT2" Version 2.1.0, revision of September 6, 2007, with some adaptions and additions. Double parentheses within the comments column enclose my explanation and notes on my operationalisation.

\begin{tabular}{|c|c|c|}
\hline Meaning & Symbol & Comments \\
\hline timestamp & $<\mathrm{TIME}=\mathrm{X}>$ & time in seconds from start of recording \\
\hline word truncated/cut-off & wor- & word not completed as projected (en dash) \\
\hline final intonation & . & intonation signals finality (period/full stop) \\
\hline continuing intonation & , & intonation signals continuation (comma) \\
\hline appeal intonation & $?$ & appeal intonation \\
\hline truncated intonation & - & aborting projected IU (em dash) \\
\hline $\begin{array}{l}\text { high rising tunes } \\
\text { (on statements) }\end{array}$ & $\begin{array}{l}<\mathrm{H} \nearrow> \\
<\mathrm{L} \nearrow>\end{array}$ & $\begin{array}{l}\text { equivalent to } \mathrm{H}^{*} \mathrm{H}-\mathrm{H} \% \text { in ToBI notion } \\
\text { equivalent to } \mathrm{L}^{*} \mathrm{H}-\mathrm{H} \% \text { in ToBI notion }\end{array}$ \\
\hline overlap (first set) & {$[$ ] } & align left square brackets vertically \\
\hline overlap (2nd set) & {$\left[\begin{array}{ll}2 & ]\end{array}\right]$} & $\begin{array}{l}\text { align left bracket and index with } \\
\text { subscript number }\end{array}$ \\
\hline hold/micropause & . & $\begin{array}{l}\text { less than } 150 \text { milliseconds; brief silence, } \\
\text { break in phonation }\end{array}$ \\
\hline pause, timed & $(1.2)$ & $\begin{array}{l}\text { pause duration in seconds ((over } 150 \\
\text { milliseconds to nearest tenth of a second)) }\end{array}$ \\
\hline stressed word & $\wedge$ & $\begin{array}{l}\text { ((unpredictable stress or a heavily } \\
\text { stressed word)) (circumflex accent) }\end{array}$ \\
\hline lag/prosodic length & $:$ & $\begin{array}{l}\text { lengthening of segment, slowing of local } \\
\text { tempo }\end{array}$ \\
\hline heavy aspirated & word_h & $\begin{array}{l}\text { suffixed, for strongly aspirated stop } \\
\text { consonant release; not = exhalation }\end{array}$ \\
\hline variant & ${ }_{-}</ æ />$ & $\begin{array}{l}\text { IPA symbol(s) for varying forms in AusE } \\
\text { attached to word. Largely those the focus } \\
\text { of study }\end{array}$ \\
\hline sound & $-^{\mid æ /}$ & $\begin{array}{l}\text { ((IPA symbol(s) attached to word. Used } \\
\text { for clarity in some instances }))\end{array}$ \\
\hline in-breath & $(\mathrm{H})$ & audible inhalation \\
\hline
\end{tabular}


(Continued)

\begin{tabular}{|c|c|c|}
\hline Meaning & Symbol & Comments \\
\hline nasal in-breath & $(H)^{N}$ & in-breath with mouth closed \\
\hline laugh-gasp & $(\mathrm{H})^{\circledR}$ & $\begin{array}{l}\text { in-breath when out of breath from } \\
\text { laughing ((or breath with a laugh quality } \\
\text { - heavier)) }\end{array}$ \\
\hline out-breath & $(\mathrm{Hx})$ & audible exhalation \\
\hline laugh & a & one symbol per pulse of laughter \\
\hline $\begin{array}{l}\text { laugh, voiceless } \\
\text { release }\end{array}$ & $\mathrm{Q}^{\mathrm{H}}$ & superscript upper-case $\mathrm{H}$ \\
\hline laugh, nasal release & $a^{N}$ & superscript upper-case $\mathrm{N}$ \\
\hline vocalism & $(D E S C R I P T I O N)$ & $\begin{array}{l}\text { various notations: (COUGH), (SNIFF), } \\
\text { etc. ((just (VOCALISM) for partial } \\
\text { sounds which aren't recoverable)) }\end{array}$ \\
\hline glottal sound & $\left(\frac{\circ}{0}\right)$ & separate "word" marks separate vocalism \\
\hline comment & $(($ WORDS $))$ & analyst's perspective inserted in transcript \\
\hline unintelligible & \#\#\# & one \# per indecipherable syllable \\
\hline uncertain hearing & \#you're \#sure & marks transcribed word as uncertain \\
\hline pseudograph & Jill & name change for anonymity (tilde) \\
\hline creaky & $<\frac{\circ}{0}>$ um $\langle/ \%$ & ((For all manners / (slash) marks the end $))$ \\
\hline voice quality & $<$ SMILE $>$ & marks e.g., smiling, breathy production \\
\hline laugh voice & $<Q>$ & $\begin{array}{l}\text { laughing while speaking ((more of a } \\
\text { laugh quality than pulses)) }\end{array}$ \\
\hline vox: voice of another & $<\mathrm{VOX}>$ & $\begin{array}{l}\text { ((sometimes just a change in pitch or } \\
\text { loudness, etc., but clearly representing } \\
\text { someone else's speech)) }\end{array}$ \\
\hline $\begin{array}{l}\text { voice of another, } \\
((+ \text { type }))\end{array}$ & $<\mathrm{VOX}=\mathrm{DUMB}>$ & $\begin{array}{l}\text { specify voice quality (e.g., stereotype } \\
\text { voice) }\end{array}$ \\
\hline vos: voice of self & $<\operatorname{VOS}>$ & self or Self (group). \\
\hline forte, loud & $<F>$ & \\
\hline piano, attenuated & $<\mathrm{P}>$ & $\begin{array}{l}\text { quiet speech ((quieter than surrounding } \\
\text { speech, usually by about } 10 \mathrm{~dB}))\end{array}$ \\
\hline high pitch (region) & $<\mathrm{HI}>$ & \\
\hline slow speech & $<$ LENTO $>$ & \\
\hline non-vocal event & $\{E V E N T\}$ & $\begin{array}{l}\text { general pattern for acts, events (open- } \\
\text { ended) }\end{array}$ \\
\hline
\end{tabular}




\section{Introduction}

\subsection{A background for Australian English}

When the English language first arrived in Australia, the invaders brought with them diverse regional varieties and histories. For a long time, perhaps until well into the twentieth century for some speakers, English in Australia was used to express Englishness or at least Britishness. The transported varieties did, however, lose their foreignness, converging and changing to create a new variety of English: Australian English.

The first discussions of Australian English being a variety were met with outrage from many Australians (Damousi, 2010; Delbridge, 2001; Schneider, 2007). Differing from "motherland" English varieties was seen as error; in fact, divergence from Received Pronunciation (henceforth RP) was seen as an abomination and perversion. Delbridge (2001) suggests that the first changes in this opinion were due to the work of A. G. Mitchell. Mitchell advocated for Australian English from 1940 , although his ideas were frequently met with hostility and the campaign was a lifetime's work (Damousi, 2010, p. 237; Delbridge, 2001).

Schneider (2007) links changes to much greater historical events. Although some aspects of the formation and recognition of Australian English are unique in their specific historical, social and political details, the general experience parallels those of other countries in similar positions. Schneider has proposed the Dynamic Model, which describes the processes through which postcolonial societies transform English from a borrowed language into their own established varieties: becoming New Englishes. The transplanted English moves through five phases: foundation, exonormative stablisation, nativisation, endonormative stablisation and differentiation. Transition from phase 3 , nativisation, to the next is often the result of Event $X$. This event is an extraordinary happening which calls into question the relationship with the "mother country". Specifically, it reveals that the esteem held for the "mother country" is not reciprocated. Event X is a catalyst with the linguistic consequence of starting a movement from the English just incorporating local elements, to a phase where new norms are accepted. Schneider proposes that for Australia, Event X was during the Second World War, when under threat of an attack from the Japanese air force in 1942, after the Fall of Singapore, Australian troops fighting overseas were not permitted to return and defend 
Australia. The Australian government had to ask the United States of America (US) for assistance. The view that this was a defining moment in national history is supported by Blainey in the classic historical work The Tyranny of Distance (1966). Blainey points out that these events marked not only the cessation of the previous type of relationship with the United Kingdom of Britain (UK) but the beginning of a reconceptualisation of Australia, with an awareness of its geographical position. The accompanying desire for greater self-sufficiency and local identity was, according to Schneider, also evidenced in the position of Australian English.

In accord with Schneider (2007), Horvath (1985) states that it was in the 1940s and 1950s that it began to be permissible to sound Australian. However, B. Moore (2008) argues that the UK's ambition to join the European Economic Community in the early 1960s, suggesting a change in trade and political alliances, was the key event that fundamentally changed the "mother country" relationship and understandings of Australia, with linguistic changes following. Clyne (1997) and Blair (1993) see movement to acceptance of local norms as occurring later again, in the early 1970s. Leitner (2004b) views real acceptance of Australian English as beginning in the 1970s, starting with the accent and flowing on to other linguistic systems. Contrary to all these authors, Eagleson (1982) suggests that complaints about Australian English from the general public were as common in 1982 as they had ever been. Few other authors note continuing disapproval of Australian English. Such unhappiness with local forms of speech and feelings of linguistic insecurity though are commonplace in postcolonial societies.

Another major event, which scholars agree on the significance of, occurred at the height of nationalist pride around the bicentenary (in 1988): the recently elevated status and increased acceptance of the new variety was encapsulated in dictionaries of Australian English. The Macquarie Dictionary was a dictionary that aimed to codify a national standard rather than listing slang and colloquialisms as earlier dictionaries had. First published in 1981, it was emblematic of a new period, and the Australian National Dictionary was published soon after (Delbridge, 2001).

It seems likely, bringing these accounts together, that the rumblings of change regarding acceptance of local norms began in the early 1940s and that such views were mainstream by the 1970s. The celebration of Australian English led to codification in the $1980 \mathrm{~s}$, but there remained, and continues to be, diversity in opinion on its legitimacy and merit, especially when compared to (the ideals of) British English (BrE).

From a contemporary perspective, Australian English can be considered as a variety of English spoken by many people in Australia, potentially along with other languages and varieties of English (for a discussion of other varieties of English in Australia, see Leitner, 2004a). It is the English taught in schools, used in the media and frequently heard on the street as well as codified in dictionaries and style guides. Australian English may be used by people from diverse backgrounds, including Indigenous Australians, long-term migrants and more recent migrants who have studied in the Australian education system. ${ }^{1}$ My definition does not include the problematic notion "standard" and hence exclude commonly used 
forms (Lippi-Green, 1997; Milroy \& Milroy, 1985/2012). Furthermore, I do not want to equate Australian English with being Australian; someone could speak Australian English and not identify as Australian or indeed identify as Australian but not speak Australian English. The definition of Australian English outlined here is henceforth AusE.

\subsection{Understanding Australian English via social meanings of variation}

The endeavour described in this book is an empirical exploration of social meanings of variation via the analysis of linguistic practices and folklinguistic evaluation. It is a contemporary sociolinguistic study and contributes to the field by placing "centre stage" data which are often dismissed or only mentioned fleetingly to support analysis rather than being the object of analysis themselves. The study adds to what is known about variation in AusE and sheds light on some of the important language ideologies and local identities in Australian society. The insights have potential implications for studies elsewhere in theoretical and methodological approach but also the language ideologies and identities in English and even other languages. The incorporation of mechanisms for the evaluation of language, mention and voicing, allow new insights into the achievement of folklinguistic accounts. This book therefore contributes to the literature on Australian English and World Englishes but also the study of folklinguistics and sociolinguistics.

As a volume on variation, it engages with research in the variationist tradition, but it departs radically from traditional methodology in numerous ways. Labovian methodology was a reaction to what had gone before it, in particular introspective data and claims that variation was usually free and best ignored. Labov's work and the tradition that follows it demonstrates that variation is linguistically structured, correlates with social categories and can model language change (Cameron, 1990). It is systematic, principled and quantitative, giving it great strength as rigorous analysis. As with all methodologies, it imposes a set of restrictions on what can be studied and learnt. Most notably the linguistic variable has limitations placed on it which rule out a good deal of variation, perhaps even complete linguistic systems (see Section 2.5.2). Furthermore, the quantitative mass of data often leads to a lack of consideration of social meanings and speakers' views, which are not easily represented numerically, except in extremely generalised forms. The social context of variation is also deemphasised and only presented in broad terms.

The qualitative turn in many fields has made clear that qualitative data can provide powerful insights. Variationist work has been supplemented with qualitative methods such as ethnography and discourse analysis, greatly enriching the work and better representing speakers and their own understandings of their social world. Recent greater engagement in theory has encouraged looking outside of sociolinguistics to better understand language usage (Bucholtz \& Hall, 2008; Coupland, 2001b, 2016). This is evident in research investigating very different topics and engaging with diverse theories and disciplines to illuminate sociolinguistic 


\section{Introduction}

practices (e.g., Bucholtz, 1999; Coupland, 2001a; Eckert, 2000; Johnstone \& Kiesling, 2008; E. Moore \& Podesva, 2009; Rampton, 1995; Schilling-Estes, 2004; Snell, 2010; Zhang, 2008). These studies have uncovered new understandings of linguistic practices, enlivening the field and making a space for contemporary sociolinguistic scholarship.

The project presented in this book in fact does not employ the usual quantitative approach so crucial to most studies of variation. This is in the belief that such analysis is insufficient for full understandings of social meaning. By attending to language in context and using discourse analysis to look closely at how people talk about language, as well as use it, new insights can be gained with respect to both variations and their social meanings. The study explores Discourse (with a capital $\langle\mathrm{D}>$ ) via discourse: learning about prevailing ideas in a culture by examining the discussion of language within a context. The data sources for the analysis here are also somewhat at odds with traditional sociolinguistic research, in that self-reporting and the speaker's discussion of language are often viewed as highly unreliable. I argue that, with due attention to the ideological nature of such reports, they are both valid and rich sources of information.

This book might be described as a third wave study, in Eckert's (2018) terminology, because its primary concerns relate to social meaning, although it differs on other criteria so the alignment is only partial. It could also be described as sociocultural linguistics in the frameworks it relies on and its interdisciplinary borrowing (Bucholtz \& Hall, 2008). Alternatively, it could be seen as part of sociolinguistics in its original, open conceptualisation and its more recent embracing of newer perspectives from social theory: contemporary sociolinguistics. It thus provides a very different account of AusE than found in most existing books on the topic in addition to using novel methods.

\subsection{Overview of the book}

In the next chapter (Chapter 2), the focus turns to outlining the concept of social meaning and the ideas it encompasses. I present a detailed model of the social meaning of language variation, based on an integrated account that draws particularly on the ideas of indexical orders (Silverstein, 2003), indirect indexicality (Ochs, 1992), the positionality principle (Bucholtz \& Hall, 2005), the indexical field (Eckert, 2008) and the semiotic processes of language ideologies (Gal \& Irvine, 1995; Irvine \& Gal, 2000). This creates a whole of the deeply related parts of language ideologies, indexicality, identity and linguistic variation. In Chapter 3, consideration turns to folklinguistics, a medium through which the social meanings are instantiated at varying levels of explicitness. The study of social meaning and folklinguistics are brought together in the presentation of the details of research, including an outline of analysis, participants and the Australian city of Melbourne.

In the analysis chapters following Chapters 2 and 3, their ideas and details are applied to Australian English one linguistic system and variable at a time: Chapter 4, phonetic and phonological; Chapter 5, lexical; and Chapter 6 discourse and grammatical variations. Each of these provides valuable detail on variations in English 
and an account of their occurrence and evaluations in AusE. In Chapter 7, the findings are drawn together across linguistic systems, providing the Salient Local Others as local type identities which were key in the folklinguistic accounts examined in this project. The uncovered language ideologies relating to Australian English are also described with reference to the findings of the current study but also how they are evident elsewhere. Chapter 7 includes the book's conclusion, showing that the study has provided rich insights into folklinguistics and social meaning in Australian English.

\section{Note}

1 Malcolm and Königsberg (2001) suggest that Indigenous Australians may never feel they can truly enact Indigenous identities through Australian English. It is important though to recognise that many Indigenous Australians may use Australian English and the existence of Aboriginal Englishes is not a reason to exclude Indigenous people from definitions.

\section{References}

Blainey, G. (1966). The tyranny of distance. Melbourne: Sun Books.

Blair, D. (1993). Australian English and Australian national identity. In G. Schulz (Ed.), The languages of Australia (pp. 62-70). Canberra: Highland Press.

Bucholtz, M. (1999). Why be normal? Language and identity practices in a community of nerd girls. Language in Society, 28(2), 203-223.

Bucholtz, M., \& Hall, K. (2005). Identity and interaction: A sociocultural linguistic approach. Discourse Studies, 7(4-5), 585-614.

Bucholtz, M., \& Hall, K. (2008). All of the above: New coalitions in sociocultural linguistics. Journal of Sociolinguistics, 12(4), 401-431.

Cameron, D. (1990). Demythologizing sociolinguistics: Why language does not reflect society. In J. E. Joseph \& T. J. Taylor (Eds.), Ideologies of language (pp. 79-93). London; New York: Routledge.

Clyne, M. (1997). Pluricentric languages and national identity: An antipodean view. In E. W. Schneider (Ed.), Englishes around the world: Studies in honour of Manfred Görlach (Vol. 2, pp. 287-299). Amsterdam; Philadelphia: John Benjamins.

Coupland, N. (2001a). Dialect stylization in radio talk. Language in Society, 30(3), 345-375.

Coupland, N. (2001b). Introduction: Sociolinguistic theory and social theory. In N. Coupland, S. Sarangi \& C. N. Candlin (Eds.), Sociolinguistics and social theory (pp. 1-26). London: Longman.

Coupland, N. (Ed.). (2016). Sociolinguistics: Theoretical debates. Cambridge; New York: Cambridge University Press.

Damousi, J. (2010). Colonial voices: A cultural history of English in Australia, 1840-1940. Cambridge: Cambridge University Press.

Delbridge, A. (2001). Lexicography and national identity: The Australian experience. In D. Blair \& P. C. Collins (Eds.), English in Australia (pp. 303-316). Amsterdam; Philadelphia: John Benjamins.

Eagleson, R. D. (1982). English in Australia and New Zealand. In R. W. Bailey \& M. Görlach (Eds.), English as a world language (pp. 415-439). Ann Arbor, MI: University of Michigan Press. 


\section{Introduction}

Eckert, P. (2000). Linguistic variation as social practice. Malden, MA; Oxford: Blackwell.

Eckert, P. (2008). Variation and the indexical field. Journal of Sociolinguistics, 12(4), 453-476.

Eckert, P. (2018). Meaning and linguistic variation: The third wave in sociolinguistics. Cambridge: Cambridge University Press.

Gal, S., \& Irvine, J. T. (1995). The boundaries of languages and disciplines: How ideologies construct differences. Social Research, 62(4), 967-1001.

Horvath, B. M. (1985). Variation in Australian English: The sociolects of Sydney. Cambridge; New York: Cambridge University Press.

Irvine, J. T., \& Gal, S. (2000). Language ideology and linguistic differentiation. In P. V. Kroskrity (Ed.), Regimes of language: Ideologies, polities, and identities (pp. 35-84). Santa Fe, NM: School of American Research Press.

Johnstone, B., \& Kiesling, S. F. (2008). Indexicality and experience: Exploring the meanings of /aw/-monophthongization in Pittsburgh. Journal of Sociolinguistics, 12(1), 5-33.

Leitner, G. (2004a). Australia's many voices: Ethnic Englishes, Indigenous and migrant languages: Policy and education. Berlin; New York: Mouton de Gruyter.

Leitner, G. (2004b). Beyond Mitchell's views on the history of Australian English. Australian Journal of Linguistics, 24(1), 99-125.

Lippi-Green, R. (1997). The standard language myth. In English with an accent: Language, ideology, and discrimination in the United States (pp. 53-62). London; New York: Routledge.

Malcolm, I. G., \& Königsberg, P. (2001, October 4-7). Factors affecting the acquisition and use of the standard dialect by Aboriginal youth. Paper presented at Pacific Linguistics Second Language Research Forum, Honolulu, HI. Retrieved from http://eric.ed.gov/ ERICDocs/data/ericdocs2sq1/content_storage_01/0000019b/80/1a/6a/79.pdf

Milroy, J., \& Milroy, L. (1985/2012). Authority in language: Investigating Standard English (4th ed.). London; New York: Routledge.

Moore, B. (2008). Speaking our language: The story of Australian English. Melbourne: Oxford University Press.

Moore, E., \& Podesva, R. J. (2009). Style, indexicality, and the social meaning of tag questions. Language in Society, 38(4), 447-485.

Ochs, E. (1992). Indexing gender. In A. Duranti \& C. Goodwin (Eds.), Rethinking context: Language as an interactive phenomenon (pp. 335-358). Cambridge: Cambridge University Press.

Rampton, B. (1995). Crossing: Language and ethnicity among adolescents. London; New York: Longman.

Schilling-Estes, N. (2004). Constructing ethnicity in interaction. Journal of Sociolinguistics, 8(2), 163-195.

Schneider, E. W. (2007). Postcolonial English: Varieties around the world. Cambridge: Cambridge University Press.

Silverstein, M. (2003). Indexical order and the dialectics of sociolinguistic life. Language and Communication, 23(3-4), 193-229.

Snell, J. (2010). From sociolinguistic variation to socially strategic stylisation. Journal of Sociolinguistics, 14(5), 630-656.

Zhang, Q. (2008). Rhotacization and the 'Beijing smooth operator': The social meaning of a linguistic variable. Journal of Sociolinguistics, 12(2), 201-222. 


\section{Conceptualising social meaning}

share insights yet the existing literature does not offer a complete account of their relationships to one another.

At this point, the interactants have barely been mentioned, but of course, this is a hugely important part of social meaning. For social meaning requires, on at least some level, interlocutors who agree on what is happening in an interaction. As Gumperz and Cook-Gumperz state, "the ideologically inscribed distinctions of language operate as resources to enable members of a group to select or highlight certain features of speech that others bound by the same ideology recognize" (2007, p. 485). This shared recognition is pivotal to all of the concepts subsumed here under social meaning. In the next chapter, the focus turns to exploring the design of this study of social meaning, examining dimensions of folklinguistic discourse and its investigation, and the people and context of this study.

\section{Notes}

1 Speaker includes those who use sign languages. While speakers reduces social actors to one element of their cultural practice, this is probably accurate given my focus on linguistic meaning making over all other semiotic resources.

2 There is no symbolism in the relative amount of space taken up by each part of the circle; this is a function of their orthography in English. Likewise, the use of the same font size is a graphic device to form the ring, not a suggestion that these elements are equal in size.

\section{References}

Auer, P., Arnhold, J., \& Bueno-Aniola, C. (2007). Being a 'colono' and being 'daitsch' in Rio Grande do Sul: Language choice and linguistic heterogeneity as a resource for social categorisation. In P. Auer (Ed.), Style and social identities: Alternative approaches to linguistic heterogeneity (pp. 85-120). Berlin; New York: Mouton de Gruyter.

Bailey, B. (2007). Language alternation as a resource for identity negotiations among Dominican American bilinguals. In P. Auer (Ed.), Style and social identities: Alternative approaches to linguistic heterogeneity (pp. 29-55). Berlin; New York: Mouton de Gruyter.

Bell, A. (1984). Language style as audience design. Language in Society, 13(2), 145-204.

Bell, A. (2001). Back in style: Reworking audience design. In P. Eckert \& J. R. Rickford (Eds.), Style and sociolinguistic variation (pp. 139-169). Cambridge; New York: Cambridge University Press.

Benwell, B., \& Stokoe, E. (2006). Theorising discourse and identity. In Discourse and identity (pp. 17-47). Edinburgh: Edinburgh University Press.

Blommaert, J., Collins, J., Heller, M., Rampton, B., Slembrouck, S., \& Verschueren, J. (2001). Introduction. Critique of Anthropology, 21(1), 5-12.

Bourdieu, P. (1991). Language and symbolic power (G. Raymond \& M. Adamson, Trans.). Cambridge, MA: Harvard University Press.

Bucholtz, M. (2003). Sociolinguistic nostalgia and the authentication of identity. Journal of Sociolinguistics, 7(3), 398-416.

Bucholtz, M. (2009). From stance to style: Gender, interaction, and indexicality in Mexican immigrant youth slang. In A. Jaffe (Ed.), Stance: Sociolinguistic perspectives (pp. 146170). Oxford; New York: Oxford University Press. 
Bucholtz, M., \& Hall, K. (2004a). Language and identity. In A. Duranti (Ed.), A companion to linguistic anthropology (pp. 369-394). Malden, MA: Blackwell.

Bucholtz, M., \& Hall, K. (2004b). Theorizing identity in language and sexuality research. Language in Society, 33(4), 469-515.

Bucholtz, M., \& Hall, K. (2005). Identity and interaction: A sociocultural linguistic approach. Discourse Studies, 7(4-5), 585-614.

Butler, J. (1990). Gender trouble: Feminism and the subversion of identity. New York: Routledge.

Cameron, D. (1990). Demythologizing sociolinguistics: Why language does not reflect society. In J. E. Joseph \& T. J. Taylor (Eds.), Ideologies of language (pp. 79-93). London; New York: Routledge.

Cameron, D. (1995). Verbal hygiene. London: Routledge.

Cheshire, J. (2005). Syntactic variation and beyond: Gender and social class variation in the use of discourse-new markers. Journal of Sociolinguistics, 9(4), 479-508.

Coupland, N. (1998). What is sociolinguistic theory? Journal of Sociolinguistics, 2(1), $110-117$.

Coupland, N. (2001a). Introduction: Sociolinguistic theory and social theory. In N. Coupland, S. Sarangi \& C. N. Candlin (Eds.), Sociolinguistics and social theory (pp. 1-26). London: Longman.

Coupland, N. (2001b). Language situation, and the relational self: Theorizing dialect-style in sociolinguistics. In P. Eckert \& J. R. Rickford (Eds.), Style and sociolinguistic variation (pp. 185-210). Cambridge; New York: Cambridge University Press.

Coupland, N. (2007). Style: Language variation and identity. Cambridge: Cambridge University Press.

Coupland, N. (2016). Introduction: Sociolinguistic theory and the practice of sociolinguistics. In N. Coupland (Ed.), Sociolinguistics: Theoretical debates (pp. 1-34). Cambridge; New York: Cambridge University Press.

Coupland, N., \& Jaworski, A. (2004). Sociolinguistic perspectives on metalanguage: Reflexivity, evaluation and ideology. In A. Jaworski, N. Coupland \& D. Galasiński (Eds.), Metalanguage: Social and ideological perspectives (pp. 15-52). Berlin; New York: Mouton de Gruyter.

De Fina, A. (2006). Group identity, narrative and self-representations. In A. De Fina, D. Schiffrin \& M. G. W. Bamberg (Eds.), Discourse and identity (pp. 351-375). Cambridge: Cambridge University Press.

De Fina, A., Schiffrin, D., \& Bamberg, M. G. W. (2006). Introduction. In A. De Fina, D. Schiffrin \& M. G. W. Bamberg (Eds.), Discourse and identity (pp. 1-23). Cambridge: Cambridge University Press.

Dines, E. R. (1980). Variation in discourse: 'And stuff like that'. Language in Society, 9(1), 13-31.

Du Bois, J. W. (2007). The stance triangle. In R. Englebretson (Ed.), Stancetaking in discourse: Subjectivity, evaluation, interaction (pp. 139-182). Amsterdam; Philadelphia: John Benjamins.

Eckert, P. (2000). Linguistic variation as social practice. Malden, MA; Oxford: Blackwell.

Eckert, P. (2008). Variation and the indexical field. Journal of Sociolinguistics, 12(4), 453-476.

Eckert, P., \& Labov, W. (2017). Phonetics, phonology and social meaning. Journal of Sociolinguistics, 21(4), 467-496. 


\section{Conceptualising social meaning}

Gal, S. (2005). Language ideologies compared: Metaphors and circulations of public and private. Journal of Linguistic Anthropology, 15(1), 23-37.

Gal, S. (2006). Language, its stakes and its effects. In R. E. Goodin \& C. Tily (Eds.), The Oxford handbook of contextual political analysis (pp. 376-391). Oxford: Oxford University Press.

Gal, S., \& Irvine, J. T. (1995). The boundaries of languages and disciplines: How ideologies construct differences. Social Research, 62(4), 967-1001.

Gumperz, J. J., \& Cook-Gumperz, J. (2007). A postscript: Style and identity in interactional sociolinguistics. In P. Auer (Ed.), Style and social identities: Alternative approaches to linguistic heterogeneity (pp. 477-501). Berlin; New York: Mouton de Gruyter.

Hall, S. (1996). Who needs 'identity’? In S. Hall \& P. Du Gay (Eds.), Questions of cultural identity (pp. 1-17). London; Thousand Oaks, CA: Sage.

Hall, S. (1997). The work of representation. In Representation: Cultural representations and signifying practices (pp. 15-64). London: Sage; The Open University.

Hodge, R., \& Kress, G. R. (1988/1997). Social semiotics, style and ideology. In N. Coupland \& A. Jaworski (Eds.), Sociolinguistics: A reader and coursebook (pp. 49-54). New York: Palgrave Macmillan. [Reprinted from Style as ideology. In H. R. Hodge \& G. Kress, Social semiotics (pp. 83-91). Cambridge: Polity Press.].

Irvine, J. T. (1989). When talk isn't cheap: Language and political economy. American Ethnologist, 16(2), 248-267.

Irvine, J. T. (2001). 'Style' as distinctiveness: The culture and ideology of linguistic differentiation. In P. Eckert \& J. R. Rickford (Eds.), Style and sociolinguistic variation (pp. 21-43). Cambridge; New York: Cambridge University Press.

Irvine, J. T., \& Gal, S. (2000). Language ideology and linguistic differentiation. In P. V. Kroskrity (Ed.), Regimes of language: Ideologies, polities, and identities (pp. 35-84). Santa Fe, NM: School of American Research Press.

Jaffe, A. (2009). Introduction. In A. Jaffe (Ed.), Stance: Sociolinguistic perspectives (pp. 3-28). Oxford; New York: Oxford University Press.

Johnstone, B., Andrus, J., \& Danielson, A. (2006). Mobility, indexicality, and the enregisterment of 'Pittsburghese'. Journal of English Linguistics, 34(2), 77-104.

Johnstone, B., \& Kiesling, S. F. (2008). Indexicality and experience: Exploring the meanings of /aw/-monophthongization in Pittsburgh. Journal of Sociolinguistics, 12(1), $5-33$.

Kiesling, S. F. (2004). Norms and social meaning in language use: Indexicality, stance, and cultural models. In S. F. Kiesling \& C. B. Paulston (Eds.), Intercultural discourse and communication: The essential readings (pp. 92-104). Oxford: Blackwell.

Kiesling, S. F. (2009). Style as stance: Stance as the explanation for patterns of sociolinguistic variation. In A. Jaffe (Ed.), Stance: Sociolinguistic perspectives (pp. 171-194). Oxford; New York: Oxford University Press.

Kiesling, S. F. (2010). Introduction: Rethinking indirection and the indexical cycle. Journal of Pragmatics, 42(2), 279-282.

Kroskrity, P. V. (2000). Regimenting languages: Language ideological perspectives. In P. V. Kroskrity (Ed.), Regimes of language: Ideologies, polities, and identities (pp. 1-34). Santa Fe, NM: School of American Research Press.

Kroskrity, P. V. (2004). Language ideologies. In A. Duranti (Ed.), A companion to linguistic anthropology. Malden, MA: Blackwell.

Labov, W. (1966). The social stratification of English in New York City. Washington, DC: Center for Applied Linguistics. 
Labov, W. (1971). The study of language in its social context. In J. A. Fishman (Ed.), Advances in the sociology of language (Vol. 1, pp. 152-216). The Hague: Mouton.

Labov, W. (1972). Sociolinguistic patterns. Philadelphia: University of Pennsylvania Press.

Labov, W. (2001). The anatomy of style-shifting. In P. Eckert \& J. R. Rickford (Eds.), Style and sociolinguistic variation (pp. 85-108). Cambridge; New York: Cambridge University Press.

Lavandera, B. R. (1978). Where does the sociolinguistic variable stop? Language in Society, 7(2), 171-182.

Mendoza-Denton, N. (2002). Language and identity. In J. K. Chambers, P. Trudgill \& N. Schilling-Estes (Eds.), The handbook of language variation and change (pp. 475-499). Malden, MA: Blackwell.

Moore, E., \& Carter, P. (2015). Dialect contact and distinctiveness: The social meaning of language variation in an island community. Journal of Sociolinguistics, 19(1), 3-36.

Moore, E., \& Podesva, R. J. (2009). Style, indexicality, and the social meaning of tag questions. Language in Society, 38(4), 447-485.

Ochs, E. (1992). Indexing gender. In A. Duranti \& C. Goodwin (Eds.), Rethinking context: Language as an interactive phenomenon (pp. 335-358). Cambridge: Cambridge University Press.

Ochs, E. (1993). Constructing social identity: A language socialization perspective. Research on Language and Social Interaction, 26(3), 287-306.

Pichler, H. (2010). Methods in discourse variation analysis: Reflections on the way forward. Journal of Sociolinguistics, 14(5), 581-608.

Rampton, B. (1995). Crossing: Language and ethnicity among adolescents. London; New York: Longman.

Rickford, J. R., \& Eckert, P. (2001). Introduction. In P. Eckert \& J. R. Rickford (Eds.), Style and sociolinguistic variation (pp. 1-18). Cambridge; New York: Cambridge University Press.

Sankoff, D. (1988). Sociolinguistics and syntactic variation. In F. J. Newmeyer (Ed.), Linguistics: The Cambridge survey IV: The socio-cultural context (pp. 140-161). Cambridge: Cambridge University Press.

Schilling-Estes, N. (2002). Investigating stylistic variation. In J. K. Chambers, P. Trudgill \& N. Schilling-Estes (Eds.), The handbook of language variation and change (pp. 375-401). Malden, MA: Blackwell.

Schilling-Estes, N. (2004). Constructing ethnicity in interaction. Journal of Sociolinguistics, 8(2), 163-195.

Silverstein, M. (1976). Shifters, linguistic categories, and cultural description. In K. H. Basso \& H. A. Selby (Eds.), Meaning in anthropology. Albuquerque, NM: University of New Mexico Press.

Silverstein, M. (1979). Language structure and linguistic ideology. In P. R. Clyne, F. C. Hanks \& C. L. Hofbauer (Eds.), The elements: A parasession on linguistic units and levels (pp. 193-247). Chicago: Chicago Linguistic Society.

Silverstein, M. (1998). The uses and utility of ideology: A commentary. In B. B. Schieffelin, K. A. Woolard \& P. V. Kroskrity (Eds.), Language ideologies: Practice and theory (pp. 123-145). New York: Oxford University Press.

Silverstein, M. (2003). Indexical order and the dialectics of sociolinguistic life. Language and Communication, 23(3-4), 193-229.

Tagliamonte, S. A. (2006). Analysing sociolinguistic variation. New York: Cambridge University Press. 


\section{Conceptualising social meaning}

Weedon, C. (1997). Feminist practice and poststructuralist theory (2nd ed.). London: Blackwell.

Wolfram, W. (1993). Identifying and interpreting variables. In D. R. Preston \& J. G. Fought (Eds.), American dialect research (pp. 193-221). Amsterdam; Philadelphia: John Benjamins.

Woolard, K. A. (1985). Language variation and cultural hegemony: Toward an integration of sociolinguistic and social theory. American Ethnologist, 12(4), 738-748.

Woolard, K. A. (1998). Introduction: Language ideology as a field of inquiry. In B. B. Schieffelin, K. A. Woolard \& P. V. Kroskrity (Eds.), Language ideologies: Practice and theory (pp. 3-47). New York: Oxford University Press.

Woolard, K. A. (2008). Why dat now? Linguistic-anthropological contributions to the explanation of sociolinguistic icons and change. Journal of Sociolinguistics, 12(4), 432-452.

Woolard, K. A., \& Schieffelin, B. B. (1994). Language ideology. Annual Review of Anthropology, 23, 55-82.

Zhang, Q. (2008). Rhotacization and the 'Beijing smooth operator': The social meaning of a linguistic variable. Journal of Sociolinguistics, 12(2), 201-222. 
(Niedzielski \& Preston, 2000), and these participants can still be thought of as folklinguists, despite having studied regional and social variation in AusE (see also Severin, 2016).

\subsection{In conclusion}

To understand the place of folklinguistics within (socio)linguistics, I have presented some of its history and various claims of the limitations and "nature" of folk-metapragmatic accounts. I have discussed how evaluations of language are not limited to overt mention but can be done through voicings. The analysis of folklinguistics, in its many guises, is not "problematic": it has strengths, limitations and dilemmas. I have also described the data and its analysis followed by introducing the context and people of the study. In Chapters 4 to 6 , the interview and sometimes questionnaire data are analysed by linguistic system and by variation with the use, mention and voicing of each considered, as applicable. In these analyses, what studies of folklinguistics can do is shown, providing new perspectives on variation in AusE.

\section{Notes}

1 I refer interested readers to Preston's work (especially, Preston, 1993, 1996, 2000).

2 I suggest that, subclassifying them using Goffman and Bakhtin's insights outlined here, performance speech, short-lived crossing, mock varieties and stylisation can all be considered within a framework of voicing as I present it in this book (Penry Williams, 2018).

3 Melbourne's population continues to rapidly increase, and the 2016 Census data show 4.48 million residents in Greater Melbourne and the ABS estimate a 2.5\% growth from 2017-2018 to 4.96 million (see www.abs.gov.au/).

\section{References}

Aijmer, K. (2002). English discourse particles: Evidence from a corpus. Amsterdam; Philadelphia: John Benjamins.

Australian Bureau of Statistics [ABS]. (2007a). 2006 Census tables: Census of population and housing, Melbourne (statistical division). Vic. Cat. No. 2068.0. Canberra: ABS.

Australian Bureau of Statistics [ABS]. (2007b). Melbourne (Statistical Division). Canberra: ABS.

Australian Bureau of Statistics [ABS]. (2008). National Regional Profile, Melbourne, 2002 to 2006. Cat. No. 1379.0.55.001. Canberra: ABS.

Bakhtin, M. M. (1981). The dialogic imagination (C. Emerson \& M. Holquist, Trans.). Austin, TX: University of Texas Press.

Bakhtin, M. M. (1984). The problems of Dostoevsky's poetics (C. Emerson, Trans.). Manchester: Manchester University Press.

Bakhtin, M. M. (1986). The problem of speech genres (V. W. McGee, Trans.). In C. Emerson \& M. Holquist (Eds.), Speech genres and other late essays (pp. 60-102). Austin, TX: University of Texas Press.

Bauman, R., \& Briggs, C. L. (1990). Poetics and performance as critical perspectives on language and social life. Annual Review of Anthropology, 19, 59-88. 
Bayard, D., Weatherall, A., Gallois, C., \& Pittam, J. (2001). Pax Americana? Accent attitudinal evaluations in New Zealand, Australia and America. Journal of Sociolinguistics, $5(1), 22-49$.

Bloomfield, L. (1944). Secondary and tertiary responses to language. Language, 20(2), 45-55.

Boas, F. (1911). Introduction to the handbook of American Indian languages. In F. Boas (Ed.), Bulletin of the bureau of American ethnology (pp. 1-83). Washington, DC: Government Printing Office.

Boersma, P., \& Weenink, D. (1992/2008). Praat: Doing phonetics by computer (Version 5.0.03) [Software]. Retrieved from www.praat.org

Bradley, D., \& Bradley, M. (2001). Changing attitudes to Australian English. In D. Blair \& P. C. Collins (Eds.), English in Australia (pp. 271-286). Amsterdam; Philadelphia: John Benjamins.

Briggs, C. L. (1986). Learning how to ask: A sociolinguistic appraisal of the role of the interview in social science research. Cambridge; New York: Cambridge University Press.

Bucholtz, M. (2000). The politics of transcription. Journal of Pragmatics, 32(10), $1439-1465$.

Bucholtz, M. (2008, June 10). Language ideologies as identity work. Paper presented at Sociolinguisticsfest '08, Bloomington, IN.

Bucholtz, M., \& Hall, K. (2005). Identity and interaction: A sociocultural linguistic approach. Discourse Studies, 7(4-5), 585-614.

Cameron, D. (2004). Out of the bottle: The social life of metalanguage. In A. Jaworski, N. Coupland \& D. Galasiński (Eds.), Metalanguage: Social and ideological perspectives (pp. 311-321). Berlin; New York: Mouton de Gruyter.

Chambers, J. K. (1995). Sociolinguistic theory: Linguistic variation and its social significance. Cambridge, MA: Blackwell.

Chun, E. W. (2004). Ideologies of legitimate mockery: Margaret Cho's revoicings of Mock Asian. Pragmatics, 14(2-3), 263-289.

Clyne, M., \& Kipp, S. (1997). Trends and changes in home language use and shift in Australia, 1986-1996. Journal of Multilingual and Multicultural Development, 18(6), 451-473.

Coupland, N. (2001). Dialect stylization in radio talk. Language in Society, 30(3), 345-375.

Coupland, N. (2007). Style: Language variation and identity. Cambridge: Cambridge University Press.

De Fina, A., \& Perrino, S. (2011). Introduction: Interviews vs. 'natural' contexts: A false dilemma. Language in Society, 40(1), 1-11.

Deppermann, A. (2007). Playing with the voice of the other: Stylized Kanaksprak in conversations among German adolescents. In P. Auer (Ed.), Style and social identities: Alternative approaches to linguistic heterogeneity (pp. 325-360). Berlin; New York: Mouton de Gruyter.

Du Bois, J. W. (2006). Representing discourse (a work in progress). Retrieved from www. linguistics.ucsb.edu/projects/transcription/representing

Du Bois, J. W. (2007). The stance triangle. In R. Englebretson (Ed.), Stancetaking in discourse: Subjectivity, evaluation, interaction (pp. 139-182). Amsterdam; Philadelphia: John Benjamins.

Du Bois, J. W., Cumming, S., Schuetze-Coburn, S., \& Paolino, D. (1992). Discourse transcription. Santa Barbara Papers in Linguistics, 4. 
Du Bois, J. W., Schuetze-Coburn, S., Cumming, S., \& Paolino, D. (1993). Outline of discourse transcription. In J. A. Edwards \& M. D. Lampert (Eds.), In talking data: Transcription and coding in discourse research (pp. 4-89). Hillsdale, NJ: Erlbaum.

Eagleson, R. D. (1982). English in Australia and New Zealand. In R. W. Bailey \& M. Görlach (Eds.), English as a world language (pp. 415-439). Ann Arbor, MI: University of Michigan Press.

Eckert, P. (2000). Linguistic variation as social practice. Malden, MA; Oxford: Blackwell.

Edwards, J. R. (1982). Language attitudes and their implications among English speakers.

In E. B. Ryan \& H. Giles (Eds.), Attitudes towards language variation: Social and applied contexts (pp. 20-33). London: Edward Arnold.

Gal, S. (2006). Language, its stakes and its effects. In R. E. Goodin \& C. Tily (Eds.), The Oxford handbook of contextual political analysis (pp. 376-391). Oxford: Oxford University Press.

Garrett, P. (2010). Attitudes to language. New York: Cambridge University Press.

Garrett, P., Coupland, N., \& Williams, A. (2003). Investigating language attitudes: Social meanings of dialect, ethnicity, and performance. Cardiff: University of Wales Press.

Garrett, P., Coupland, N., \& Williams, A. (2004). Adolescents' lexical repertoires of peer evaluation: Boring prats and English snobs. In A. Jaworski, N. Coupland \& D. Galasiński (Eds.), Metalanguage: Social and ideological perspectives (pp. 193-225). Berlin; New York: Mouton de Gruyter.

Garrett, P., Williams, A., \& Evans, B. (2005). Attitudinal data from New Zealand, Australia, the US and UK about each other's Englishes: Recent changes or consequences of methodologies? Multilingua, 24(3), 211-235.

Goffman, E. (1981). Footing. In Forms of talk (pp. 124-159). Philadelphia: University of Pennsylvania Press.

Görlach, M. (1988/1991). Australian English: Standards, stigmata, stereotypes and statistics. In Englishes: Studies in varieties of English 1984-1988 (pp. 144-173). Amsterdam; Philadelphia: John Benjamins.

Günthner, S. (1999). Polyphony and the 'layering or voices' in reported dialogues: An analysis of the use of prosodic devices in everyday reported speech. Journal of Pragmatics, $31(5), 685-708$.

Hammarström, G. (1987). Irritating expressions in Australian English. Language and Speech, 30(4), 357-372.

Hanks, W. F. (1993). Metalanguage and pragmatics of deixis. In J. A. Lucy (Ed.), Reflexive language: Reported speech and metapragmatics (pp. 127-157). Cambridge: Cambridge University Press.

Heritage, J. (2018). Turn-initial particles in English: The cases of oh and well. In J. Heritage \& M.-L. Sorjonen (Eds.), Between turn and sequence: Turn-initial particles across languages (pp. 155-190). Amsterdam: John Benjamins.

Hill, J. H. (1999). Styling locally, styling globally: What does it mean? Journal of Sociolinguistics, 3(4), 542-556.

Hoenigswald, H. (1966). A proposal for the study of folk-linguistics. In W. Bright (Ed.), Sociolinguistics: Proceedings of the UCLA Sociolinguistics conference, 1964 (pp. 16-20). The Hague; Paris: Mouton de Gruyter.

Irvine, J. T. (2001). 'Style' as distinctiveness: The culture and ideology of linguistic differentiation. In P. Eckert \& J. R. Rickford (Eds.), Style and sociolinguistic variation (pp. 21-43). Cambridge; New York: Cambridge University Press.

Kendall, T. (2006/2009). Convert TextGrid transcripts to readable text [Software]. Retrieved from http://ncslaap.lib.ncsu.edu/tools/praat_to_text.php 
Kroskrity, P. V. (2000). Regimenting languages: Language ideological perspectives. In P. V. Kroskrity (Ed.), Regimes of language: Ideologies, polities, and identities (pp. 1-34). Santa Fe, NM: School of American Research Press.

Labov, W. (1966). The social stratification of English in New York City. Washington, DC: Center for Applied Linguistics.

Labov, W. (1971). The study of language in its social context. In J. A. Fishman (Ed.), Advances in the sociology of language (Vol. 1, pp. 152-216). The Hague: Mouton de Gruyter.

Labov, W. (1972). Sociolinguistic patterns. Philadelphia: University of Pennsylvania Press.

Labov, W. (2001). Principles of linguistic change: Social factors. Malden, MA; Oxford: Blackwell.

Lambert, W. E., Hodgson, R. C., Gardner, R. C., \& Fillenbaum, S. (1960). Evaluational reactions to spoken languages. Journal of Abnormal and Social Psychology, 60(1), 44-51.

Liebscher, G., \& Dailey-O'Cain, J. (2009). Language attitudes in interaction. Journal of Sociolinguistics, 13(2), 195-222.

Lucy, J. A. (1993). Reflexive language and the human disciplines. In J. A. Lucy (Ed.), Reflexive language: Reported speech and metapragmatics (pp.9-32). Cambridge: Cambridge University Press.

Meyer, D. Z., \& Avery, L. M. (2009). Excel as a qualitative data analysis tool. Field Methods, 21(1), 91-112.

Mulder, J. (2007). Establishing linguistics in secondary education in Victoria, Australia. Language and Linguistics Compass, 1(3), 133-154.

Mulder, J., Thompson, S. A., \& Penry Williams, C. (2009). Final but in Australian English conversation. In P. C. Collins, P. Peters \& A. Smith (Eds.), Comparative studies in Australian and New Zealand English (pp. 339-359). Amsterdam; Philadelphia: John Benjamins.

Niedzielski, N. A., \& Preston, D. R. (2000). Folk linguistics. Berlin; New York: Mouton de Gruyter.

Niedzielski, N. A., \& Preston, D. R. (2007). Folk pragmatics. In J. Verschueren, J.-O. Östman \& (in collaboration with) E. Versluys (Eds.), Handbook of pragmatics (pp. 146-155). Amsterdam; Philadelphia: John Benjamins.

Penry Williams, C. (2007). Heteronyms in Australian English: Self reported usage and assessments. In R. Loughnane, C. Penry Williams \& J. Verhoeven (Eds.), In between wor(l)ds: Transformation and translation: School of languages and linguistics postgraduate research papers on language and literature (Vol. 6, pp. 135-148). Melbourne: University of Melbourne.

Penry Williams, C. (2018, June 27-30). The analytic importance of metapragmatics in variationist methodology: Voicings within Australian English. Paper presented at Sociolinguistics Symposium, Auckland.

Penry Williams, C. (2019). Appeals to semiotic registers in ethno-metapragmatic accounts of variation. Journal of Linguistic Anthropology, Advance online publication. doi: 10.1111/jola.12213

Preston, D. R. (1985). The Lit'1 Abner syndrome: Written representations of speech. American Speech, 60(4), 328-336.

Preston, D. R. (1993). The uses of folk linguistics. International Journal of Applied Linguistics, 3(2), 181-259.

Preston, D. R. (1994). Content-oriented discourse analysis and folk linguistics. Language Sciences, 16(2), 285-331. 
Preston, D. R. (1996). Whaddayaknow? The modes of folk linguistic awareness. Language Awareness, 5(1), 40-77.

Preston, D. R. (2000). A renewed proposal for the study of folk linguistics. In P. Griffen, J. Kreeft Peyton, W. Wolfram \& R. W. Fasold (Eds.), Language in action: New studies of language in society: Papers presented to Roger W. Shuy (pp. 113-138). Creeskill, NY: Hampton Press.

Preston, D. R. (2004). Folk metalanguage. In A. Jaworski, N. Coupland \& D. Galasiński (Eds.), Metalanguage: Social and ideological perspectives (pp. 75-101). Berlin; New York: Mouton de Gruyter.

Preston, D. R. (2019). How to trick respondents into revealing implicit attitudes-talk to them. Linguistics Vanguard, 5(s1).

Rampton, B. (1995). Crossing: Language and ethnicity among adolescents. London; New York: Longman.

Rodgers, E. (2017). Towards a typology of discourse-based approaches to language attitudes. Language and Communication, 56, 82-94.

Rosseel, L., \& Grondelaers, S. (2019). Implicitness and experimental methods in language variation research. Linguistics Vanguard, 5(s1).

Ryan, E. B., Giles, H., \& Sebastian, R. J. (1982). An integrative perspective for the study of attitudes toward language. In E. B. Ryan \& H. Giles (Eds.), Attitudes towards language variation: Social and applied contexts (pp. 1-19). London: Edward Arnold.

Schiffrin, D. (1987/1999). Oh as a marker of information management. In A. Jaworski \& N. Coupland (Eds.), The discourse reader (pp. 275-288). London: Routledge. [Reprinted from Discourse markers (pp. 73-101). Cambridge: Cambridge University Press].

Schilling-Estes, N. (1998). Investigating 'self-conscious' speech: The performance register in Ocracoke English. Language in Society, 27(1), 53-83.

Schilling-Estes, N. (2002). Investigating stylistic variation. In J. K. Chambers, P. Trudgill \& N. Schilling-Estes (Eds.), The handbook of language variation and change (pp. 375-401). Malden, MA: Blackwell.

Schilling-Estes, N. (2004). Constructing ethnicity in interaction. Journal of Sociolinguistics, 8(2), 163-195.

Severin, A. A. (2016). Vigilance or tolerance? Younger speakers' attitudes to Australian English usage. Australian Journal of Linguistics, 37(2), 156-181.

Silverstein, M. (1979). Language structure and linguistic ideology. In P. R. Clyne, F. C. Hanks \& C. L. Hofbauer (Eds.), The elements: A parasession on linguistic units and levels (pp. 193-247). Chicago: Chicago Linguistic Society.

Silverstein, M. (1981). Limits of awareness. Sociolinguistic Working Paper, 84, 1-30.

Silverstein, M. (2003). Indexical order and the dialectics of sociolinguistic life. Language and Communication, 23(3-4), 193-229.

Trudgill, P. (1983/1998). Sex and covert prestige. In J. Coates (Ed.), Language and gender: A reader (pp. 21-28). Oxford: Blackwell. [Reprinted from On dialect: Social and geographical perspectives (pp. 169-177). Oxford: Blackwell].

Trudgill, P. (1986). Dialects in contact. Oxford: Blackwell.

Verschueren, J. (2000). Notes on the role of metapragmatic awareness in language use. Pragmatics, 10(4), 439-456.

Winter, J. (1992). Discourse as a resource: Methods of collecting language attitudes. Australian Review of Applied Linguistics, 15(1), 1-22.

Wolfram, W. (2007). Sociolinguistic folklore in the study of African American English. Language and Linguistics Compass, 1(4), 292-313. 


\section{Studying social meaning via folklinguistics}

Wolfson, N. (1976). Speech events and natural speech: Some implications for sociolinguistic methodology. Language in Society, 5(2), 189-209.

Woolard, K. A. (1998). Introduction: Language ideology as a field of inquiry. In B. B. Schieffelin, K. A. Woolard \& P. V. Kroskrity (Eds.), Language ideologies: Practice and theory (pp. 3-47). New York: Oxford University Press.

Zilles, A. M. S., \& King, K. (2005). Self-presentation in sociolinguistic interviews: Identities and language variation in Panambi, Brazil. Journal of Sociolinguistics, 9(1), 74-94. 
of AusE. It is important also to understand that the sociolects and their associations, as employed in the literature and by questionnaire participants, often function as a proxy for social class. Indeed, this may be part of the common reversion to three types of accents in AusE despite contradictory findings, with Broad, General and Cultivated tacitly representing working, middle and higher social classes, although this has been shown to be inaccurate by Horvath (1985) and Cox and Palethorpe (2010). Furthermore, judgements of forms as posh or bogan create social types with strong indexical links to social class. Whilst origin was often important, it was usually less clearly discussed and attributed, with this largely functioning to Other a form (those who use it) and erase variation.

The language ideologies found in the discourse surrounding this linguistic system, with varying levels of engagement and conviction, included notions of correctness, particularly of only one form being correct in one time and place. There was also some discussion of the Americanisation of AusE as a source of innovative forms. My discussion of the tradition of sociolects in the AusE literature highlights another ideology, hinted at elsewhere in this chapter - that the imagined egalitarianism of Australian society is evident in its language use. While there are elements of this that I do not object to, when presented in this way, its simplification of history, society and culture relies on erasure, iconisation and naturalisation that should not be ignored.

In the following two chapters, analysis turns to lexical and then grammatical and discourse variations, building on what has been found here whilst simultaneously providing insights into very different parts of AusE.

\section{Notes}

1 The study is also notable for its inclusion of participants who were not monolingual native speakers. Her analysis included the categories of "Ethnic Broad" and "Accented" for some interviewees of Italian and Greek heritage.

2 This usage, "banned" in many Victorian schools due to it being perceived as offensive to gay people, means something similar to "unfashionable or annoying" (MD) or generally a negative evaluation. Lame was used in the same way around the same time.

3 I did examine the textbooks for the subject, and some of the features in the questionnaires were included, but it is not possible to know precisely what the students from the large number of schools had studied. Furthermore, the diversity of responses and the negative assessments suggest that they were not simply reproducing what they had learnt in class. Again, I note the resistance to non-evaluative understandings of one's own language (variety).

4 I have recently told a large number of AusE speakers that I am moving to Derby, UK, using START: the local production. Many of them responded with NURSE or asked me about the pronunciation.

5 Shall was also voiced alongside /de:ns/ by Ojal and darling evaluated as pretentious (see Section 5.5).

6 This extract is also presented in Penry Williams (2019) with expanded analysis to support the argument original to that paper.

7 Those pronunciations listed with the full vowel as "Originally US" were not in the MD in older editions (e.g., they were not listed in 2011). 
8 I have on occasion heard folklinguistic comment on these particular words and together. I have a recording of such comment from a local community radio station. This centres on one of the presenters' pronunciation of milk being noted, "picked up", which leads to a long explanation. At the last moment, he playfully adds that he needs to have a good look at himself in the mirror voicing the mirror with a /e/-like pronunciation.

9 Well is known to be produced quite differently (Loakes, 2008).

\section{References}

Billington, R. (2011). Location, location, location! Regional characteristics and national patterns of change in the vowels of Melbourne adolescents. Australian Journal of Linguistics, 31(3), 275-303.

Bradley, D. (1980). Regional differences in Australian English phonology. Working Papers in Linguistics, University of Melbourne, 6, 73-93.

Bradley, D. (1991). /æ/ and /a:/ in Australian English. In J. Cheshire (Ed.), English around the world: Sociolinguistic perspectives (pp. 227-234). Cambridge: Cambridge University Press.

Bradley, D. (2003). Mixed sources of Australian English. Australian Journal of Linguistics, 23(2), 143-150.

Bradley, D. (2004). Regional characteristics of Australian English: Phonology. In E. W. Schneider, B. Kortmann, K. Burridge, R. Mesthrie \& C. Upton (Eds.), A handbook of varieties of English: A multimedia reference tool (Vol. 1, pp. 645-655). Berlin; New York: Mouton de Gruyter.

Bryant, P. (1989). Regional variation in the Australian lexicon. In P. C. Collins \& D. Blair (Eds.), Australian English: The language of a new society (pp. 301-314). Brisbane: University of Queensland Press.

Burridge, K. (2005). Weeds in the garden of words: Further observations on the tangled history of the English language. Cambridge: Cambridge University Press.

Burridge, K. (2010). Linguistic cleanliness is next to godliness: Taboo and purism. English Today, 26(2), 3-13.

Clark, J. E. (1989). Some proposals for a revised phonetic transcription of Australian English. In P. C. Collins \& D. Blair (Eds.), Australian English: The language of a new society (pp. 205-213). Brisbane: University of Queensland Press.

Cox, F., \& Palethorpe, S. (2004). The border effect: Vowel differences across the NSWVictorian border. In C. Moskovsky (Ed.), Proceedings of the 2003 Australian Linguistic Society conference. Retrieved from www.als.asn.au/proceedings/als2003.html

Cox, F., \& Palethorpe, S. (2007). Illustrations of the IPA: Australian English. Journal of the International Phonetic Association, 37(3), 341-350.

Cox, F., \& Palethorpe, S. (2009). Audio illustrations. Retrieved from http://clas.mq.edu.au/ australian-voices/australian-voices

Cox, F., \& Palethorpe, S. (2010). Broadness variation in Australian English speaking females. In M. Tabain, J. Fletcher, D. Grayden, J. Hajek \& A. Butcher (Eds.), Proceedings of the 13th Australasian international conference on speech science and technology (pp. 175-178). Retrieved from http://assta.org/sst/SST-10/SST2010/PDF/AUTHOR/ST100040.PDF

Durie, M., \& Hajek, J. (1994). A revised standard phonemic orthography for Australian English vowels. Australian Journal of Linguistics, 14(1), 93-107.

Eckert, P. (2008). Variation and the indexical field. Journal of Sociolinguistics, 12(4), 453-476. 
Ford, C. (2019). Acquisition of gender-specific sociophonetic cues in the speech of primary school-aged children. Unpublished doctoral dissertation, La Trobe University, Melbourne.

Fritz, C. W. A. (2004). From Plato to Aristotle: Investigating early Australian English. Australian Journal of Linguistics, 24(1), 57-97.

Goffman, E. (1981). Footing. In Forms of talk (pp. 124-159). Philadelphia: University of Pennsylvania Press.

Görlach, M. (1987/1991). Colonial Lag? The alleged conservative character of American English and other 'colonial' varieties. In Englishes: Studies in varieties of English 1984-1988 (pp. 90-107). Amsterdam; Philadelphia: John Benjamins.

Harrington, J., Cox, F., \& Evans, Z. (1997). An acoustic and phonetic study of broad, general, and cultivated Australian English vowels. Australian Journal of Linguistics, 17(2), 155-184.

Hickey, R. (2007). Irish English: History and present-day forms. Cambridge; New York: Cambridge University Press.

Horvath, B. M. (1985). Variation in Australian English: The sociolects of Sydney. Cambridge; New York: Cambridge University Press.

Horvath, B. M. (2004). Australian English: Phonology. In E. W. Schneider, B. Kortmann, K. Burridge, R. Mesthrie \& C. Upton (Eds.), A handbook of varieties of English: A multimedia reference tool (Vol. 1, pp. 625-664). Berlin; New York: Mouton de Gruyter.

Horvath, B. M., \& Horvath, R. J. (2001). A geolinguistics of short A in Australian English. In D. Blair \& P. C. Collins (Eds.), English in Australia (pp. 341-355). Amsterdam; Philadelphia: John Benjamins.

Jones, M. J., \& McDougall, K. (2006). A comparative acoustic study of Australian English fricated /t/: Assessing the Irish (English) link. In P. Warren \& C. I. Watson (Eds.), Proceedings of the 11th Australian international conference on speech science \& technology (pp. 6-12). Auckland: Australasian Speech Science and Technology Association. Retrieved from www.assta.org/sst/2006/sst2006-16.pdf

Kiesling, S. F. (2007). Australian Englishes [Review of the books Australia's many voices: Australian English: The national language and Australia's many voices: Ethnic Englishes, Indigenous languages and migrant languages: Policy and education, by G. Leitner]. World Englishes, 26(3), 388-390.

Kiesling, S. F. (2011). [Review of the book Speaking our language: The story of Australian English, by B. Moore]. World Englishes, 32(1), 111-114.

Korhonen, M. (2017). Perspectives on the Americanisation of Australian English: A sociolinguistic study of variation. Helsinki: University of Helsinki.

Leitner, G. (2004). Australia's many voices: Australian English: The national language. Berlin; New York: Mouton de Gruyter.

Loakes, D. (2008, June 30-July 2). Phonetic evidence for neutralisation of prelateral /ae/ and lel in Melbourne English. Poster session presented at Laboratory Phonology 11 Conference, Wellington.

Loakes, D., Clothier, J. J., Hajek, J., \& Fletcher, J. (2014). An investigation of the /el/ $/ æ \mathrm{l} /$ merger in Australian English: A pilot study on production and perception in southwest Victoria. Australian Journal of Linguistics, 34(4), 436-452.

Loakes, D., Hajek, J., \& Fletcher, J. (2017). Can you t[æ]ll I'm from M[æ]lbourne? An overview of the DRESS and TRAP vowels before /1/ as a regional accent marker in Australian English. English World-Wide, 38(1), 29-49. 
Macquarie Dictionary Online. (2003-2019). Sydney: Macquarie Dictionary Publishers, an Imprint of Pan Macmillan Australia. Retrieved from www.macquariedictionary. com.au

Millar, J. B., O'Kane, M., \& Bryant, P. (1989). Design, collection, and description of a database of spoken Australian English. Australian Journal of Linguistics, 9(1), 165-189.

Mitchell, A. G. (1946). The pronunciation of English in Australia. Sydney: Angus and Robertson.

Mitchell, A. G., \& Delbridge, A. (1965a). The pronunciation of English in Australia. Sydney: Angus and Robertson.

Mitchell, A. G., \& Delbridge, A. (1965b). The speech of Australian adolescents. Sydney: Angus and Robertson.

Mulder, J., \& Penry Williams, C. (2014). Documenting unacknowledged inheritances in contemporary Australian English. In L. Gawne \& J. Vaughan (Eds.), Selected papers from the 44th conference of the Australian Linguistic Society, 2013 (pp. 160-177). Melbourne: University of Melbourne. Retrieved from http://bit.ly/ALS2013Proceedings

Palethorpe, S., \& Cox, F. (2003, December 7-10). Vowel modification in pre-lateral environments. Paper presented at International Seminars on Speech Production, Sydney.

Peeters, B. (2004). Tall poppies and egalitarianism in Australian discourse. English WorldWide, 25(1), 1-25.

Penry Williams, C. (2019). Appeals to semiotic registers in ethno-metapragmatic accounts of variation. Journal of Linguistic Anthropology, Advance online publication. doi: 10.1111 /jola.12213

Peters, P. (1998). Australian English. In R. J. Bell \& P. Bell (Eds.), Americanization and Australia (pp. 32-44). Sydney: University of New South Wales Press.

Preston, D. R. (1996). Whaddayaknow? The modes of folk linguistic awareness. Language Awareness, 5(1), 40-77.

Saito, H. (1990). Difference in the placement of word-stress in Australian English and RP. Area and Culture Studies, 41, 15-21.

Taylor, B. A. (1989). American, British and other foreign influences on Australian English since World War II. In P. C. Collins \& D. Blair (Eds.), Australian English: The language of a new society (pp. 225-254). Brisbane: University of Queensland Press.

Thomas, B., \& Hay, J. (2006). A pleasant malady: The ellen/allan merger in New Zealand English. Te Reo, 48, 69-93.

Tollfree, L. (2001). Variation and change in Australian consonants: Reduction of /t/. In D. Blair \& P. C. Collins (Eds.), English in Australia (pp. 45-69). Amsterdam; Philadelphia: John Benjamins.

Tottie, G. (2002). An introduction to American English. Malden, MA; Oxford: Blackwell.

Trevian, I. (2007). Stress-neutral endings in contemporary British English: An updated overview. Language Sciences, 29(2-3), 426-450.

Trudgill, P. (1986). Dialects in contact. Oxford: Blackwell.

Trudgill, P., \& Hannah, J. (2013). International English: A guide to the varieties of Standard English (5th ed.). Abingdon; New York: Routledge.

Wells, J. C. (1982). Accents of English (Vols. 1-3). Cambridge; New York: Cambridge University Press.

Welna, J. (1999). Downs and ups of short [e] before nonprevocalic [r], or late middle English e-lowering. Studia Anglica Posnaniensia, 34, 55-72. Retrieved from http://ifa.amu.edu. $\mathrm{pl} / \mathrm{sap} /$ files/34/03welna.pdf 


\section{Phonetic and phonological variation}

Withington, R. (1943). Transplanted names: Comments on some changes of pronunciation in America brought about by a migration across the Atlantic. College English, 5(2), $80-84$.

Wolfram, W. (2007). Sociolinguistic folklore in the study of African American English. Language and Linguistics Compass, 1(4), 292-313. 


\section{Lexical variation}

Social meanings of lexical variation engaged with ideologies of "Americanisation" but not to the extent suggested by commentators on the topic, and the evaluations of cookie and elevator were different. For some participants, cookie was understood as different to biscuit; amongst others, there was support for the idea that cookie in particular was a "threat" to something Australian, although no one particularly highlighted a fondness for biscuit. From their accounts, regional variation appeared a less important social meaning, with the social types which existed beyond this introduced and words evaluated as ocker or associated with pretention without this being clearly tied to place. In addition to engaging with the previously found social types of the ocker and posh types (those associated with pretentious language), there was engagement with the wog.

\section{Notes}

1 There is also white out which is not a trademark but Wite-Out is.

2 While these numbers are small to be converted into percentages, it is useful in this study to allow quick comparison with the much larger survey population.

3 Distinguishing Frankston North from Frankston implies finer local distinctions due to the relative proximity of Pakenham. Sarah discussed an Old Pakenham/New Pakenham divide which, from her description, is multifaceted but partly exemplified in voting preferences. The larger issue related to the increasing population Sarah viewed as Pakenham becoming increasingly suburban rather than rural.

4 This extract is also presented in Penry Williams (2019) with expanded analysis to support the argument original to that paper.

5 In informal discussions, an English linguist and etymologist suggested that EngE also distinguishes cookie from biscuit, although we did not discuss the properties of each. Note also that, like BrE, AusE biscuit can include savory items, but AmE does not have a term which is superordinate to its crackers and cookies (Algeo, 1989, p. 239).

6 In response to my query to online support, regarding if there was a way I could search the dictionary for trademarks, the editor kindly supplied this list of words.

7 Dead horse is a fairly common rhyming slang phrase that references, via rhyme, tomato sauce, traditionally the most common condiment, for example, at barbeques.

8 Soccer has sometimes been referred to as wog ball in opposition to other football codes (Tsolidis \& Pollard, 2009, p. 433), although this is no longer common now it is far more mainstream.

9 High numbers of discontinued IUs were typical of Ian's speech.

\section{References}

Algeo, J. (1989). British-American lexical differences: A typology of interdialectal variation. In O. García \& R. Otheguy (Eds.), English across cultures, cultures across English (pp. 219-241). Berlin; New York: Mouton de Gruyter.

Alimoradian, K. (2014). 'Makes me feel more Aussie': Ethnic identity and vocative mate in Australia. Australian Journal of Linguistics, 34(4), 599-623.

Australian Broadcasting Corporation. (2005). Australian word map. Retrieved from http:// abc.net.au/wordmap/

Bakhtin, M. M. (1984). The problems of Dostoevsky's poetics (C. Emerson, Trans.). Manchester: Manchester University Press.

Bloomfield, L. (1944). Secondary and tertiary responses to language. Language, 20(2), 45-55.

Bayard, D. (1989). Me say that? No way! The social correlates of American lexical diffusion in New Zealand English. Te Reo, 32, 17-60. 
Bryant, P. (1985). Regional variation in the Australian English lexicon. Australian Journal of Linguistics, 5(1), 55-66.

Bryant, P. (1989a). Regional variation in the Australian lexicon. In P. C. Collins \& D. Blair (Eds.), Australian English: The language of a new society (pp. 301-314). Brisbane: University of Queensland Press.

Bryant, P. (1989b). The south-east lexical usage region of Australian English. Australian Journal of Linguistics, 9(1), 85-134.

Bryant, P. (1997). A dialect survey of the lexicon of Australian English. English WorldWide, 18(2), 211-241.

Bucholtz, M. (2009). From stance to style: Gender, interaction, and indexicality in Mexican immigrant youth slang. In A. Jaffe (Ed.), Stance: Sociolinguistic perspectives (pp. 146170). Oxford; New York: Oxford University Press.

Burridge, K., \& Mulder, J. (1998). English in Australia and New Zealand: An introduction to its history, structure and use. Melbourne: Oxford University Press.

Butters, R. R. (2010). Trademark linguistics. Trademarks: Language that one owns. In A. Johnson \& M. Coulthard (Eds.), The Routledge handbook of forensic linguistics (pp. 351-364). Abingdon: Routledge.

Chambers, J. K. (1990-1995). The Canada-US border as a vanishing isogloss: The evidence of chesterfield. Journal of English Linguistics, 23(1-2), 155-166.

Chambers, J. K. (1998a). Inferring dialect from a postal questionnaire. Journal of English Linguistics, 26(3), 222-246.

Chambers, J. K. (1998b). Social embedding of changes in progress. Journal of English Linguistics, 26(1), 5-36.

Chambers, J. K. (2006, January 5). Dialect topography. Retrieved from http://dialect.topography.chass.utoronto.ca/

Clankie, S. M. (2000). Genericization: A theory of semantic broadening in the marketplace. The Northern Review, 28, 1-11.

Collins, F. (2009). Wogboy comedies and the Australian national type. In C. Simpson, R. Murawska \& L. Anthony (Eds.), Diasporas of Australian cinema (pp. 73-82, 183-198). Bristol: Intellect Books.

Collins, P. C., \& Peters, P. (2004). Australian English: Morphology and syntax. In E. W. Schneider, B. Kortmann, K. Burridge, R. Mesthrie \& C. Upton (Eds.), A handbook of varieties of English: A multimedia reference tool (Vol. 2, pp. 593-610). Berlin; New York: Mouton de Gruyter.

Condor, S. (2000). Pride and prejudice: Identity management in English people's talk about 'this country'. Discourse and Society, 11(2), 175-205.

Eagleson, R. D. (1982). English in Australia and New Zealand. In R. W. Bailey \& M. Görlach (Eds.), English as a world language (pp. 415-439). Ann Arbor, MI: University of Michigan Press.

Eckert, P. (2003). Sociolinguistics and authenticity: An elephant in the room. Journal of Sociolinguistics, 7(3), 392-431.

Gal, S., \& Irvine, J. T. (1995). The boundaries of languages and disciplines: How ideologies construct differences. Social Research, 62(4), 967-1001.

Garrett, P., Evans, B., \& Williams, A. (2006). What does the word 'globalisation' mean to you? Comparative perceptions and evaluations in Australia, New Zealand, the USA and the UK. Journal of Multilingual and Multicultural Development, 27(5), 392-412.

Görlach, M. (1988/1991). Australian English: Standards, stigmata, stereotypes and statistics. In Englishes: Studies in varieties of English 1984-1988 (pp. 144-173). Amsterdam; Philadelphia: John Benjamins. 


\section{Lexical variation}

Görlach, M. (1990). Heteronymy in International English. English World-Wide, 11(2), 239-274.

Holmes, J., Sigley, R. J., \& Terraschke, A. (2009). From chairman to chairwoman to chairperson: Exploring the move from sexist usages to gender neutrality. In P. C. Collins, P. Peters \& A. Smith (Eds.), Comparative studies in Australian and New Zealand English (pp. 183-294). Amsterdam; Philadelphia: John Benjamins.

Igboanusi, H. (2003). Knowledge, use, and attitudes towards Americanisms in Nigerian English. World Englishes, 22(4), 599-604.

Irvine, J. T. (2001). 'Style' as distinctiveness: The culture and ideology of linguistic differentiation. In P. Eckert \& J. R. Rickford (Eds.), Style and sociolinguistic variation (pp. 21-43). Cambridge; New York: Cambridge University Press.

Joseph, J. E. (2004). Language in national identities. In Language and identity: National, ethnic, religious (pp. 92-131). Basingstoke: Palgrave Macmillan.

Kidd, E., Kemp, N., \& Quinn, S. (2011). Did you have a choccie bickie this arvo? A quantitative look at Australian hypocoristics. Language Sciences, 33(3), 359-368.

Kiesling, S. F. (2004). Dude. American Speech, 79(3), 281-305.

Kiesling, S. F. (2008, June 11). Gender, interaction and meaning in linguistic variation. Paper presented at Sociolinguisticsfest '08, Bloomington, IN.

Leek, R., \& Bayard, D. (1995). Yankisms in Kiwiland from zed to zee: American lexical and pronunciation incursions in Dunedin (1984-85) and Auckland (1990). Te Reo, 38, 105-125.

Leitner, G. (2004). Australia's many voices: Australian English: The national language. Berlin; New York: Mouton de Gruyter.

Macquarie Dictionary Online. (2003-2019). Sydney: Macquarie Dictionary Publishers, an Imprint of Pan Macmillan Australia. Retrieved from www.macquariedictionary.com.au

Meyerhoff, M. (1993). Lexical shift in working class New Zealand English: Variation in the use of lexical pairs. English World-Wide, 14(2), 231-248.

Meyerhoff, M., \& Niedzielski, N. A. (2003). The globalisation of vernacular variation. Journal of Sociolinguistics, 7(4), 534-555.

Moore, B. (2001a). Australian English and Indigenous voices. In D. Blair \& P. C. Collins (Eds.), English in Australia (pp. 133-150). Amsterdam; Philadelphia: John Benjamins.

Moore, B. (2001b). Australian English: Australian identity. In B. Moore (Ed.), Who's centric now? The present state of post-colonial Englishes (pp. 44-58). Melbourne: Oxford University Press.

Moore, B. (2008). Speaking our language: The story of Australian English. Melbourne: Oxford University Press.

Moore, B. (2010). What's their story? A history of Australian words. Melbourne: Oxford University Press.

Oishi, I. (1998). American and British English in Australian usage. Seikei Hogaku, 47, 1-36.

Oliver, R., McKay, G., \& Rochecouste, J. (2002). Lexical variation among Western Australian primary school children. Australian Journal of Linguistics, 22(2), 207-229.

Pauwels, A. (1997). Of handymen and waitpersons: A linguistic evaluation of job classifieds. Australian Journal of Communication, 24(1), 58-69.

Penry Williams, C. (2007). Heteronyms in Australian English: Self reported usage and assessments. In R. Loughnane, C. Penry Williams \& J. Verhoeven (Eds.), In between wor(l)ds: Transformation and translation: School of languages and linguistics postgraduate research papers on language and literature (Vol. 6, pp. 135-148). Melbourne: University of Melbourne.

Penry Williams, C. (2019). Appeals to semiotic registers in ethno-metapragmatic accounts of variation. Journal of Linguistic Anthropology, Advance online publication. doi: $10.1111 /$ jola. 12213 
Peters, P. (1998). Australian English. In R. J. Bell \& P. Bell (Eds.), Americanization and Australia (pp. 32-44). Sydney: University of New South Wales Press.

Poyton, C. (1989). Terms of address in Australian English. In P. C. Collins \& D. Blair (Eds.), Australian English: The language of a new society (pp. 55-69). Brisbane: University of Queensland Press.

Preston, D. R. (1996). Whaddayaknow? The modes of folk linguistic awareness. Language Awareness, 5(1), 40-77.

Rendle-Short, J. (2007). 'Catherine, you're wasting your time': Address terms within the Australian political interview. Journal of Pragmatics, 39(9), 1503-1525.

Rendle-Short, J. (2009). The address term mate in Australian English: Is it still a masculine term? Australian Journal of Linguistics, 29(2), 245-268.

Rendle-Short, J. (2010). 'Mate' as a term of address in ordinary interaction. Journal of Pragmatics, 42(5), 1201-1218.

Richards, K. (2005). Word map: What words are used where in Australia. Sydney: ABC Books.

Schneider, E. W. (2007). Postcolonial English: Varieties around the world. Cambridge: Cambridge University Press.

Schneider, E. W. (2010, October 9-10). Global English(es): Diverging or converging? Paper presented at The Free Linguistics Conference [Featured speaker], Sydney.

Seal, G. (1999). Brand names. In The lingo: Listening to Australian English (pp. 79-83). Sydney: University of New South Wales Press.

Simpson, J. (2008). Hypocristics in Australian English. In K. Burridge \& B. Kortmann (Eds.), Varieties of English 3: The Pacific and Australasia (pp. 398-414). Berlin; New York: Mouton de Gruyter.

Speed, L. (2005). Life as a pizza: The comic of traditions wogsploitation films. Metro, 146-147, 136-144.

Sussex, R. (1989). The Americanisation of Australian English: Prestige models in the media. In P. C. Collins \& D. Blair (Eds.), Australian English: The language of a new society (pp. 158-168). Brisbane: University of Queensland Press.

Tollfree, L. (2001). Variation and change in Australian consonants: Reduction of /t/. In D. Blair \& P. C. Collins (Eds.), English in Australia (pp. 45-69). Amsterdam; Philadelphia: John Benjamins.

Trüb, R. (2008). American English impact on South African English: An empirical analysis of its manifestations and attitudes towards it. Unpublished doctoral dissertation, University of Regensburg, Regensburg.

Trudgill, P. (1998). World Englishes: Convergence divergence? In H. Lindquist, S. Klintborg, M. Levin \& M. Estling (Eds.), The major varieties of English: Papers from MAVEN 97 (pp. 29-34). Växjö: Acta wexionensia.

Trudgill, P. (2014). Diffusion, drift, and the irrelevance of media influence. Journal of Sociolinguistics, 18(2), 214-222.

Tsolidis, G., \& Pollard, V. (2009). Being a 'wog' in Melbourne: Young people's self-fashioning through discourses of racism. Discourse: Studies in the Cultural Politics of Education, 30(4), 427-442.

Vine, B. (1999). Americanisms in the New Zealand English lexicon. World Englishes, $18(1), 13-22$.

Warren, J. (1999). 'Wogspeak': Transformations of Australian English. Journal of Australian Studies, 62, 86-94. 


\subsubsection{Conclusions}

The final feature discussed, final particle but, was not used by participants but had a high level of self-report in the questionnaire. The evaluations from these two sources aligned, but the interviews did not also report the positive assessments of the form. Unlike other forms, it was attributed to stigmatised places within Melbourne in addition to be regionally Othered as from Queensland. Mentions and voicings produced phonetically accurate productions of final particle but yet failed to recognise that the usual contrastive function was retained in the new position. It was understood as meaningless in the traditional sense but as socially meaningful.

\subsection{In conclusion}

The data on discourse, syntactic and morphosyntactic features were particularly rich. There was not a lot of citing of grammatical "rules" or pundits, as there was from Niedzielski and Preston's (2000) participants. It is clear though that there were quite negative judgements surrounding the use of some forms with stigmatisation often more explicit than for other linguistic systems. This was frequently true of features shared with other varieties, such as IrE, northern EngE and ScotE, although they were usually seen as uniquely Australian.

Clippings and (ING) were frequent enough that the use data provide new information for the AusE literature. Use of the velar in (ING) was the only feature here associated with being articulate, formal or proper with the other assessments focussing on being a(n) ocker, Queenslander or bogan with the forms they vary with not assessed. The questionnaire data complemented and supported the evaluations of the interviewees providing a broader picture of views of the final particle but, potentially with more acceptance indicating change in use. The Queenslander was frequently invoked in the discussion of this linguistic system presenting another local social type to be discussed across systems in the following and final chapter.

\section{Notes}

1 Some of the examples and discussion are also explored in Mulder and Penry Williams (2014), including Figure 6.2.

2 I thank the Celeste Rodríguez Louro for sharing this in-draft paper with me.

3 For the vast majority of speakers, Australia contains a different initial vowel to Aussie (note possible $<$ ozzie $>$ ). There were no instances of the possible telly (TV/television). For those interested specifically in hypocoristic forms, there was one instance of Tassie ( 9 Tasmanias), KG (4 Kangaroo Ground) and Macca(')s (8 McDonald's).

4 An important difference is that Bradley and Bradley (1979) saw the student-researchers' data (D. Bradley, personal communication, April 21, 2011).

5 Note that I didn't do nothing involves some very interesting positioning of parties (see footnote 3 in Penry Williams, 2019 where this extract is also presented).

6 The second person plural form you guys was present in voicings too. It occurred on eight occasions. However, there did not seem to be any evidence of these indexing any particular types or situations. This form has been suggested to be the new unmarked plural with the loss of the masculine meaning of guys for a group of people (Heyd, 2010). Taylor attributes its presence in AusE to AmE influence (1989, p. 240). 


\section{References}

Agha, A. (2007). Language and social relations. Cambridge; New York: Cambridge University Press.

Australian Broadcasting Corporation. (2005). Australian word map. Retrieved from http:// abc.net.au/wordmap/

Baker, C. L. (1995). Contrast, discourse prominence, and intensification, with special reference to locally free reflexives in British English. Language, 71(1), 63-101.

Bauer, L. (2002). An introduction to international varieties of English. Edinburgh: Edinburgh University Press.

Bauer, L., \& Huddleston, R. (2002). Lexical word-formation. In R. Huddleston \& G. K. Pullum (Eds.), The Cambridge grammar of the English language (pp. 1621-1721). Cambridge: Cambridge University Press.

Beal, J. C. (1993). The grammar of Tyneside and Northumbrian English. In J. Milroy \& L. Milroy (Eds.), Real English: The grammar of English dialects in the British Isles (pp. 187-213). London: Longman.

Bradley, D. (2003). Mixed sources of Australian English. Australian Journal of Linguistics, 23(2), 143-150.

Bradley, D., \& Bradley, M. (1979). Melbourne vowels. Working Papers in Linguistics, University of Melbourne, 5, 64-84.

Bradley, D., \& Bradley, M. (1985). The phonetic realisation of a morpheme boundary in Australian English. In J. E. Clark (Ed.), The cultivated Australian: Festschrift in honour of Arthur Delbridge (pp. 333-340). Hamburg: Buske.

Burridge, K., \& Mulder, J. (1998). English in Australia and New Zealand: An introduction to its history, structure and use. Melbourne: Oxford University Press.

Collins, P., \& Peters, P. (2008). Australian English: Morphopology and syntax. In K. Burridge \& B. Kortmann (Eds.), Varieties of English 3: The Pacific and Australasia (pp. 341-361). Berlin; New York: Mouton de Gruyter.

Collins, P. C. (1989). Divided and debatable usage in Australian English. In P. C. Collins \& D. Blair (Eds.), Australian English: The language of a new society (pp. 138-149). Brisbane: University of Queensland Press.

D'Arcy, A. (2007). Like and language ideology: Disentangling fact from fiction. American Speech, 82(4), 386-419.

Dines, E. R. (1980). Variation in discourse: 'And stuff like that'. Language in Society, 9(1), 13-31.

Eckert, P. (2000). Linguistic variation as social practice. Malden, MA; Oxford: Blackwell.

Eckert, P. (2008). Variation and the indexical field. Journal of Sociolinguistics, 12(4), 453-476.

Eisikovits, E. (1989). Girl-talk/boy-talk: Sex differences in adolescent speech. In P. C. Collins \& D. Blair (Eds.), Australian English: The language of a new society (pp. 35-54). Brisbane: University of Queensland Press.

Eisikovits, E. (1991). Variation in subject-verb agreement in inner Sydney English. In J. Cheshire (Ed.), English around the world: Sociolinguistic perspectives (pp. 235-255). Cambridge; New York: Cambridge University Press.

Fox Tree, J. E. (2007). Folk notions of um and uh, you know, and like. Text and Talk, 27(3), 297-314.

Fritz, C. W. A. (2007). From English in Australia to Australian English: 1788-1900. Frankfurt am Main: Peter Lang. 


\section{4}

Goffman, E. (1981). Footing. In Forms of talk (pp. 124-159). Philadelphia: University of Pennsylvania Press.

Gordon, E. (1998). Anythink or nothink: A lazy variant or ancient treasure? New Zealand English Journal, 12, 25-33.

Görlach, M. (1987/1991). Colonial Lag? The alleged conservative character of American English and other 'colonial' varieties. In Englishes: Studies in varieties of English 19841988 (pp. 90-107). Amsterdam; Philadelphia: John Benjamins.

Görlach, M. (1988/1991). Australian English: Standards, stigmata, stereotypes and statistics. In Englishes: Studies in varieties of English 1984-1988 (pp. 144-173). Amsterdam; Philadelphia: John Benjamins.

Haig, Y., \& Oliver, R. (2003). Language variation and education: Teachers' perceptions. Language and Education, 17(4), 266-280.

Hammarström, G. (1987). Irritating expressions in Australian English. Language and Speech, 30(4), 357-372.

Hazen, K. (2008). (ING): A vernacular baseline for English in Appalachia. American Speech, 83(2), 116-140.

Heyd, T. (2010). How you guys doin'? Staged orality and emerging plural address in the television series Friends. American Speech, 85(1), 33-66.

Hickey, R. (2003). Rectifying a standard deficiency: Pronominal distinctions in varieties of English. In I. Taavitsainen \& A. H. Jucker (Eds.), Diachronic perspectives on address term systems (pp. 343-374). Amsterdam; Philadelphia: John Benjamins.

Hickey, R. (2004). Appendix 1: Checklist of nonstandard features. In R. Hickey (Ed.), Legacies of colonial English: Its origins and evolution (pp. 586-620). New York: Cambridge University Press.

Hickey, R. (2007). Irish English: History and present-day forms. Cambridge; New York: Cambridge University Press.

Horvath, B. M. (1985). Variation in Australian English: The sociolects of Sydney. Cambridge; New York: Cambridge University Press.

Houston, A. C. (1985). Continuity and change in English morphology: The variable (ING). Unpublished Doctoral dissertation, University of Pennsylvania, Philadelphia. Retrieved from ProQuest Dissertations and Theses database. (AAT 8515390).

Huddleston, R., \& Pullum, G. K. (2002). The Cambridge grammar of the English language. Cambridge: Cambridge University Press.

Hundt, M., Hay, J., \& Gordon, E. (2008). New Zealand English: Morphosyntax. In K. Burridge \& B. Kortmann (Eds.), Varieties of English 3: The Pacific and Australasia (pp. 305-340). Berlin; New York: Mouton de Gruyter.

Ingram, J. C. L. (1989). Connected speech processes in Australian English. Australian Journal of Linguistics, 9(1), 21-49.

Irvine, J. T., \& Gal, S. (2000). Language ideology and linguistic differentiation. In P. V. Kroskrity (Ed.), Regimes of language: Ideologies, polities, and identities (pp. 35-84). Santa Fe, NM: School of American Research Press.

Kidd, E., Kemp, N., \& Quinn, S. (2011). Did you have a choccie bickie this arvo? A quantitative look at Australian hypocoristics. Language Sciences, 33(3), 359-368.

Kiesling, S. F. (1998). Men's identities and sociolinguistic variation: The case of fraternity men. Journal of Sociolinguistics, 2(1), 69-99.

Kiesling, S. F. (2010). Introduction: Rethinking indirection and the indexical cycle. Journal of Pragmatics, 42(2), 279-282.

Kirk, J. M., \& Kallen, J. L. (2006). Irish Standard English: How Celticised? How standardised? In H. L. C. Tristram (Ed.), The Celtic Englishes IV: The interface between English and the Celtic Languages (pp. 88-113). Potsdam: Potsdam University Press. 
Kirk, J. M., \& Kallen, J. L. (2010). How Scottish is Irish Standard English? In R. M. Millar (Ed.), Northern lights, Northern words: Selected papers from the FRLSU [Forum for research on the languages of Scotland and Ulster] conference (pp. 178-213). Aberdeen: Forum for Research on the Languages of Scotland and Ireland.

König, E., \& Siemund, P. (2000). The development of complex reflexives and intensifiers in English. Diachronica, 17(1), 39-84.

Korhonen, M. (2017). Perspectives on the Americanisation of Australian English: A sociolinguistic study of variation. Helsinki: University of Helsinki.

Kortmann, B. (2006). Syntactic variation in English: A global perspective. In B. Aarts \& A. McMahon (Eds.), The handbook of English linguistics (pp. 603-624). Malden, MA; Oxford: Blackwell.

Labov, W. (1972). Sociolinguistic patterns. Philadelphia: University of Pennsylvania Press.

Labov, W. (2001). Principles of linguistic change: Social factors. Malden, MA; Oxford: Blackwell.

Lange, C. (2006). Reflexivity and intensification in Irish English and other New Englishes. In H. L. C. Tristram (Ed.), The Celtic Englishes IV: The interface between English and the Celtic Languages (pp. 259-282). Potsdam: Potsdam University Press.

Lee, D. (1989). Sociolinguistic variation in the speech of Brisbane adolescents. Australian Journal of Linguistics, 9(1), 51-72.

Leitner, G. (2004). Australia's many voices: Australian English: The national language. Berlin; New York: Mouton de Gruyter.

Miller, J. (2004). Scottish English: Morphology and syntax. In E. W. Schneider, B. Kortmann, K. Burridge, R. Mesthrie \& C. Upton (Eds.), A handbook of varieties of English: A multimedia reference tool (Vol. 2, pp. 47-72). Berlin; New York: Mouton de Gruyter.

Miller, J. (2009). Like and other discourse markers. In P. C. Collins, P. Peters \& A. Smith (Eds.), Comparative studies in Australian and New Zealand English (pp. 317-337). Amsterdam; Philadelphia: John Benjamins.

Milroy, J., \& Milroy, L. (1985/2012). Authority in language: Investigating Standard English (4th ed.). London; New York: Routledge.

Moore, E., \& Podesva, R. J. (2009). Style, indexicality, and the social meaning of tag questions. Language in Society, 38(4), 447-485.

Mulder, J., \& Penry Williams, C. (2014). Documenting unacknowledged inheritances in contemporary Australian English. In L. Gawne \& J. Vaughan (Eds.), Selected papers from the 44th conference of the Australian Linguistic Society, 2013 (pp. 160-177). Melbourne: University of Melbourne. Retrieved from http://bit.ly/ALS2013Proceedings

Mulder, J., \& Penry Williams, C. (2018). Understanding the place of Australian English: Exploring folk linguistic accounts through contemporary Australian authors. Asian Englishes, 20(1), 54-64.

Mulder, J., Penry Williams, C., \& Thompson, S. A. (2010, May 27-28). The final particlehood of but in Australian English conversation. Paper presented at International Conference on Final Particles, Rouen.

Mulder, J., \& Thompson, S. A. (2008). The grammaticization of but as a final particle in conversation. In R. Laury (Ed.), Crosslinguistic studies of clause combining: The multifunctionality of conjunctions (pp. 179-204). Amsterdam; Philadelphia: John Benjamins.

Mulder, J., Thompson, S. A., \& Penry Williams, C. (2009). Final but in Australian English conversation. In P. C. Collins, P. Peters \& A. Smith (Eds.), Comparative studies in Australian and New Zealand English (pp. 339-359). Amsterdam; Philadelphia: John Benjamins.

Niedzielski, N. A., \& Preston, D. R. (2000). Folk linguistics. Berlin; New York: Mouton de Gruyter. 
Ochs, E. (1992). Indexing gender. In A. Duranti \& C. Goodwin (Eds.), Rethinking context: Language as an interactive phenomenon (pp. 335-358). Cambridge: Cambridge University Press.

OED online. (2003-2019). Oxford: Oxford University Press. Retrieved from www.oed. com

Parker, F., Riley, K., \& Meyer, C. F. (1990). Untriggered reflexive pronouns in English. American Speech, 65(1), 50-69.

Pauwels, A. (2001). Non-sexist language reform and generic pronouns in Australian English. English World-Wide, 22(1), 105-119.

Pawley, A. (2004). Australian Vernacular English: Some grammatical characteristics. In E. W. Schneider, B. Kortmann, K. Burridge, R. Mesthrie, \& C. Upton (Eds.), A handbook of varieties of English: A multimedia reference tool (Vol. 2, pp. 611-642). Berlin; New York: Mouton de Gruyter.

Penry Williams, C. (2019). Appeals to semiotic registers in ethno-metapragmatic accounts of variation. Journal of Linguistic Anthropology, Advance online publication. doi: 10.1111/jola.12213

Penry Williams, C. (in preparation). Learning about Melbourne and Australia through linguistic play and folklinguistic discourse (working title).

Penry Williams, C., \& Korhonen, M. (2018, June 27-30). Variation and change in possession and root modality in Australian English: The declining fortunes of have got. Paper presented at Sociolinguistics Symposium, Auckland.

Penry Williams, C., \& Korhonen, M. (in preparation). A sociolinguistic perspective on the (quasi-)modals of obligation and necessity in Australian English (working title).

Peters, P. (2004). The Cambridge guide to English usage. Cambridge: Cambridge University Press.

Peters, P., \& Burridge, K. (2012). English in Australia and New Zealand. In R. Hickey (Ed.), Areal features of the Anglophone world (pp. 233-258). Berlin: Mouton de Gruyter.

Preston, D. R. (1996). Whaddayaknow? The modes of folk linguistic awareness. Language Awareness, 5(1), 40-77.

Quinn, H. (2009). Pronoun forms. In P. C. Collins, P. Peters \& A. Smith (Eds.), Comparative studies in Australian and New Zealand English (pp. 31-47). Amsterdam; Philadelphia: John Benjamins.

Quirk, R., Greenbaum, S., Leech, G. N., \& Svartvik, J. (1985). A comprehensive grammar of the English language. London; New York: Longman.

Remlinger, K. (2009). Everyone up here: Enregisterment and identity in Michigan's Keweenaw Peninsula. American Speech, 84(2), 118-137.

Richard, S., \& Rodríguez Louro, C. (2016). Narrative-embedded variation and change: The sociolinguistics of the Australian English narrative present perfect. In V. Werner, E. Seoane \& C. Suárez-Gómez (Eds.), Re-assessing the present perfect (pp. 119-145). Boston: Mouton de Gruyter.

Richards, K. (2005). Word map: What words are used where in Australia. Sydney: ABC Books.

Rodríguez Louro, C. (2013). Quotatives down under: Be like in cross-generational Australian English speech. English World-Wide, 34(1), 48-76.

Rodríguez Louro, C. (in press). Reimagining discourse-pragmatic features of Australian English. In L. Willoughby \& H. Manns (Eds.), Australian English reimagined: Structure, features and developments. Abingdon; New York: Routledge.

Severin, A. A. (2016). Vigilance or tolerance? Younger speakers' attitudes to Australian English usage. Australian Journal of Linguistics, 37(2), 156-181. 
Shnukal, A. (1982). You're gettin' somethink for nothing: Two phonological variables of Australian English. Australian Journal of Linguistics, 2(2), 197-212.

Shopen, T. (1978). Research on the variable (ing) in Canberra, Australia. Talanya, 5, 42-52.

Siemund, P. (2003). Varieties of English from a cross-linguistic perspective: Intensifiers and reflexives. In G. Rohdenburg \& B. Mondorf (Eds.), Determinants of grammatical variation in English (pp. 479-506). Berlin; New York: Mouton de Gruyter.

Silverstein, M. (1998). The uses and utility of ideology: A commentary. In B. B. Schieffelin, K. A. Woolard \& P. V. Kroskrity (Eds.), Language ideologies: Practice and theory (pp. 123-145). New York: Oxford University Press.

Silverstein, M. (2003). Indexical order and the dialectics of sociolinguistic life. Language and Communication, 23(3-4), 193-229.

Simpson, J. (2001). Hypocoristics of place-names. In D. Blair \& P. C. Collins (Eds.), English in Australia (pp. 89-112). Amsterdam; Philadelphia: John Benjamins.

Simpson, J. (2008). Hypocristics in Australian English. In K. Burridge \& B. Kortmann (Eds.), Varieties of English 3: The Pacific and Australasia (pp. 398-414). Berlin; New York: Mouton de Gruyter.

Snell, J. (2010). From sociolinguistic variation to socially strategic stylisation. Journal of Sociolinguistics, 14(5), 630-656.

Sussex, R. (2004). Abstand, ausbau, creativity and ludicity in Australian English. Australian Journal of Linguistics, 24(1), 3-19.

Tagliamonte, S. A. (2006). Analysing sociolinguistic variation. New York: Cambridge University Press.

Taylor, B. A. (1989). American, British and other foreign influences on Australian English since World War II. In P. C. Collins \& D. Blair (Eds.), Australian English: The language of a new society (pp. 225-254). Brisbane: University of Queensland Press.

Trudgill, P. (1986). Dialects in contact. Oxford: Blackwell.

Wald, B., \& Shopen, T. (1981/1985). A researcher's guide to the sociolinguistic variable (ING). In V. P. Clark, P. A. Eschholz \& A. F. Rosa (Eds.), Language: Introductory readings (4th ed., pp. 515-541). New York: St. Martin's Press. [Reprinted from T. Shopen \& J. M. Williams (Eds.), Style and variables in English (pp. 219-249). Cambridge, MA: Winthrop].

Wallenberg, J. C. (2005). The story of the American-self: A case study in morphological variation. University of Pennsylvania Working Papers in Linguistics, 11(1). Retrieved from www.ling.upenn.edu/ joelcw/papers/Wallenberg_PLC.pdf

Wells, J. C. (1982). Accents of English (Vols. 1-3). Cambridge; New York: Cambridge University Press.

Wells, J. C. (2006). English accents: Australian (i) [PowerPoint slides]. Retrieved from University College London website www.phon.ucl.ac.uk/home/wells/x202info.htm

Wierzbicka, A. (1992). Semantics, culture and cognition: Universal human cognition in culture-specific configurations. Oxford: Oxford University Press. 
researching such language ideologies does not simply recirculate them but allows for their identification and therefore their denaturalisation and contestation. Their examination reveals many similarities to language ideologies in professional accounts of AusE (Penry Williams, 2011). This is not surprising given that there is "no gaze that is not positioned" (Irvine \& Gal, 2000, p. 36), and scientific knowledge is grounded in social life (Woolard, 1998, p. 10). Awareness and understanding of folklinguistic views and language ideologies should be part of reflexive consideration of linguists' own discussions of language. This may also assist in better engagement in public debate (for a consideration of this, see Lewis, 2018 and responses in that same issue).

Across this book, piece by piece, I have shown that there is more variation in AusE than is usually described and alongside this provided a consideration of how that variation is understood via my model of social meaning. This sort of approach allows rich insights into AusE and its place in the world, including among other varieties of English. I have also aimed to show that even apparently simple metapragmatic discourse contains a depth of beliefs about language and culture when examined: that these "bad data" can be used to good effect.

\section{Notes}

1 The MD suggests that apples here might relate to the rhyming slang apples and rice "nice", based on a dessert from the early 1900 s, but that this is uncertain.

2 Before this, yobbo was perhaps more used. Arguably, yobbo is more directly linked to lower SES, social disruption and being "rough", similar to lout or ruffian. Jacqui and two questionnaire participants used yobbo in discussing language.

3 A wealthy/prestigious area within Sydney, the capital city of New South Wales.

4 This extract is also presented in Penry Williams (2019) with expanded analysis to support the argument original to that paper.

5 In AusE, usually only young children refer to or address their parents as Mummy or Daddy.

6 There are also "posh types": the minor characters Prue and Trude, whose pretension is evident in their speech (Willoughby et al., 2013). They have been noted in the linguistics literature for their use of fricated /t/ (Loakes \& McDougall, 2010).

7 I thank an anonymous reviewer for this insight.

\section{References}

Agha, A. (2007). Language and social relations. Cambridge; New York: Cambridge University Press.

Algeo, J. (1998). America is ruining the English language. In L. Bauer \& P. Trudgill (Eds.), Language myths (pp. 176-182). New York: Penguin.

Bartolo, K. F. (2008). 'Bogan': Polite or not? Cultural implications of a term in Australian slang. Griffith Working Papers in Pragmatics and Intercultural Communication, 1(1), 7-20.

Bell, R. J., \& Bell, P. (1998). Introduction: The dilemmas of ‘Americanisation'. In R. J. Bell \& P. Bell (Eds.), Americanization and Australia (pp. 1-14). Sydney: University of New South Wales Press.

Bogan.com.au. (2006). Retrieved from www.bogan.com.au 
Bourdieu, P. (1984). Distinction: A social critique of the judgement of taste (R. Nice, Trans.). Cambridge, MA: Harvard University Press.

Bradley, D. (2004). Regional characteristics of Australian English: Phonology. In E. W. Schneider, B. Kortmann, K. Burridge, R. Mesthrie \& C. Upton (Eds.), A handbook of varieties of English: A multimedia reference tool (Vol. 1, pp. 645-655). Berlin; New York: Mouton de Gruyter.

Bradley, D., \& Bradley, M. (2001). Changing attitudes to Australian English. In D. Blair \& P. C. Collins (Eds.), English in Australia (pp. 271-286). Amsterdam; Philadelphia: John Benjamins.

Brown, B., \& Brown, D. (2005). Beyond boganism. The Journal of Popular Culture, 38(4), 632-649.

Bucholtz, M., \& Hall, K. (2005). Identity and interaction: A sociocultural linguistic approach. Discourse Studies, 7(4-5), 585-614.

Butler, S. (1992). Killing off the cultural cringe by teaching Australian English. In D. Myers (Ed.), The great literacy debate: English in contemporary Australia (pp. 44-52). Melbourne: Australian Scholarly Publishing.

Cameron, D. (1995). Verbal hygiene. London: Routledge.

Collins, F. (2009). Wogboy comedies and the Australian national type. In C. Simpson, R. Murawska \& L. Anthony (Eds.), Diasporas of Australian cinema (pp. 73-82, 183-198). Bristol: Intellect Books.

Condor, S. (2000). Pride and prejudice: Identity management in English people's talk about 'this country'. Discourse and Society, 11(2), 175-205.

Coupland, N. (2009). The mediated performance of vernaculars. Journal of English Linguistics, 37(3), 284-300.

Crawford, R. (2007). 'Anyhow ... where d'yer get it, mate?': Ockerdom in adland Australia. Journal of Australian Studies, 90, 1-15, 179-180.

Crawford, R. (2010). Learning to say g'day to the world: The development of Australia's marketable image in the 1980s. Consumption Markets and Culture, 13(1), 43-59.

Eckert, P. (2000). Linguistic variation as social practice. Malden, MA; Oxford: Blackwell.

Eckert, P., \& McConnell-Ginet, S. (1999). New generalizations and explanations. Language in Society, 28(2), 185-201.

Ferguson, N. (2008). Americanisation of Australian English: Attitudes, perceptions and usage. Unpublished honours thesis, Monash University, Melbourne.

Fritz, C. W. A. (2010). A short history of Australian spelling. Australian Journal of Linguistics, 30(2), 227-281.

Goffman, E. (1963). Stigma and social identity. In Stigma: Notes on the management of spoiled identity (pp. 1-40). Englewood Cliffs, NJ: Prentice Hall.

Goffman, E. (1981). Footing. In Forms of talk (pp. 124-159). Philadelphia: University of Pennsylvania Press.

Guy, G. R. (1991). Australia. In J. Cheshire (Ed.), English around the world: Sociolinguistic perspectives (pp. 213-226). Cambridge; New York: Cambridge University Press.

Hammarström, G. (1987). Irritating expressions in Australian English. Language and Speech, 30(4), 357-372.

Hente, C. (2001). Melioration of an abuse term: Wog-from racial vilification to identity marker. Unpublished honours thesis, University of Melbourne, Melbourne.

Hundt, M. (1998). New Zealand English grammar, fact or fiction? A corpus-based study in morphosyntactic variation. Amsterdam; Philadelphia: John Benjamins. 
Irvine, J. T., \& Gal, S. (2000). Language ideology and linguistic differentiation. In P. V. Kroskrity (Ed.), Regimes of language: Ideologies, polities, and identities (pp. 35-84). Santa Fe, NM: School of American Research Press.

Jaffe, A. (2016). Indexicality, stance and fields in sociolinguistics. In N. Coupland (Ed.), Sociolinguistics: Theoretical debates (pp. 86-112). Cambridge; New York: Cambridge University Press.

Joseph, J. E. (2004). Language in national identities. In Language and identity: National, ethnic, religious (pp. 92-131). Basingstoke: Palgrave Macmillan.

Kiesling, S. F. (2005). Variation, stance and style: Word-final -er, high rising tone, and ethnicity in Australian English. English World-Wide, 26(1), 1-42.

Kiesling, S. F. (2011). [Review of the book Comparative studies in Australian and New Zealand English: Grammar and beyond]. World Englishes, 30(3), 444-457.

Labov, W. (2001). Principles of linguistic change: Social factors. Malden, MA; Oxford: Blackwell.

Leitner, G. (1984). Australian English or English in Australia: Linguistic identity or dependence in broadcast language. English World-Wide, 1(1), 55-85.

Leitner, G. (2004). Australia's many voices: Australian English: The national language. Berlin; New York: Mouton de Gruyter.

Lewis, M. C. (2018). A critique of the principle of error correction as a theory of social change. Language in Society, 47(3), 325-346.

Loakes, D., \& McDougall, K. (2010). Individual variation in the frication of voiceless plosives in Australian English: A study of twins' speech. Australian Journal of Linguistics, 30(2), 155-181.

Macquarie Dictionary Online. (2003-2019). Sydney: Macquarie Dictionary Publishers, an Imprint of Pan Macmillan Australia. Retrieved from www.macquariedictionary.com.au

McGrath, A. (1997). Sexuality and Australian identities. In W. Hudson \& G. Bolton (Eds.), Creating Australia: Changing Australian history (pp. 39-51). St. Leonards: Allen and Unwin.

Meyerhoff, M., \& Niedzielski, N. A. (2003). The globalisation of vernacular variation. Journal of Sociolinguistics, 7(4), 534-555.

Milroy, J., \& Milroy, L. (1997). Varieties and variation. In F. Coulmas (Ed.), The handbook of sociolinguistics (pp. 47-64). Oxford: Blackwell.

Niedzielski, N. A., \& Preston, D. R. (2000). Folk linguistics. Berlin; New York: Mouton de Gruyter.

Paternoster, H. J., Warr, D., \& Jacobs, K. (2018). The enigma of the bogan and its significance to class in Australia: A socio-historical analysis. Journal of Sociology, 54(3), 429-445.

Peeters, B. (2004a). Tall poppies and egalitarianism in Australian discourse. English WorldWide, 25(1), 1-25.

Peeters, B. (2004b). 'Thou shalt not be a tall poppy': Describing an Australian communicative (and behavioral) norm. Intercultural Pragmatics, 1(1), 71-92.

Penry Williams, C. (2009, August 19-21). Constructing self and other in folklinguistic accounts. Paper presented at Dialogic Language Use 2: Constructing Identity in Interpersonal Communication, Helsinki.

Penry Williams, C. (2011). Exploring social meanings of variation in Australian English. Unpublished dissertation, University of Melbourne, Melbourne.

Penry Williams, C. (2019). Appeals to semiotic registers in ethno-metapragmatic accounts of variation. Journal of Linguistic Anthropology, Advance online publication. doi: 10.1111/jola.12213 
Pini, B., McDonald, P., \& Mayes, R. (2012). Class contestations and Australia's resource boom: The emergence of the 'cashed-up bogan'. Sociology, 46(1), 142-158.

Preston, D. R. (1996). Whaddayaknow? The modes of folk linguistic awareness. Language Awareness, 5(1), 40-77.

Rattigan, N. (1988). Apotheosis of the Ocker. Journal of Popular Film and Television, 15(4), 148-155.

Rickard, J. (1998). Lovable larrikins and awful ockers. Journal of Australian Studies, 56, 78-85.

Schneider, E. W. (2007). Postcolonial English: Varieties around the world. Cambridge: Cambridge University Press.

Sitch, R. (1997). The castle [Film]. Australia: Village Roadshow.

Speed, L. (2005). Life as a pizza: The comic of traditions wogsploitation films. Metro, 146-147, 136-144.

Stuart-Smith, J. (2014). No longer an elephant in the room. Journal of Sociolinguistics, $18(2), 250-261$.

Sussex, R. (2004). Abstand, ausbau, creativity and ludicity in Australian English. Australian Journal of Linguistics, 24(1), 3-19.

Team Matt \& Jo. (2009, August 12). Are you a bogan? Matt \& Jo show blog (Fox FM). Retrieved from www.fox.com.au/shows/mattandjo/blog/matt-jo-show/blog/are-you-abogan/20090812-581r.html (no longer available).

Things bogans like. (2009). Retrieved from http://thingsboganslike.com

Tsolidis, G., \& Pollard, V. (2009). Being a 'wog' in Melbourne: Young people's self-fashioning through discourses of racism. Discourse: Studies in the Cultural Politics of Education, 30(4), 427-442.

Turnbull, S. (2004). 'Look at moiye, Kimmie, look at moiye!' Kath and Kim and the Australian comedy of taste. Media International Australia, Incorporating Culture and Policy, 113, 98-109.

Turner, G. W. (1997). Australian English as a national language. In E. W. Schneider (Ed.), Englishes around the world: Studies in honour of Manfred Görlach (Vol. 2, pp. 335349). Amsterdam; Philadelphia: John Benjamins.

Warren, J. (1999). 'Wogspeak': Transformations of Australian English. Journal of Australian Studies, 62, 86-94.

Wells, J. C. (1982). Accents of English (Vols. 1-3). Cambridge; New York: Cambridge University Press.

White, R. (1981). Inventing Australia: Images and identity 1788-1980. Sydney: Allen and Unwin.

Willoughby, L., Starks, D., \& Taylor-Leech, K. (2013). Is the cultural cringe alive and kicking? Adolescent mythscapes of Australian English in Queensland and Victoria. Australian Journal of Linguistics, 33(1), 31-50.

Woolard, K. A. (1998). Introduction: Language ideology as a field of inquiry. In B. B. Schieffelin, K. A. Woolard \& P. V. Kroskrity (Eds.), Language ideologies: Practice and theory (pp. 3-47). New York: Oxford University Press. 